Prepared for the U.S. Department of Energy under Contract DE-AC05-76RL01830

\title{
A Review of Subsurface Behavior of Plutonium and Americium at the 200-PW-1/3/6 Operable Units
}

\section{KJ Cantrell}

RG Riley

January 2008

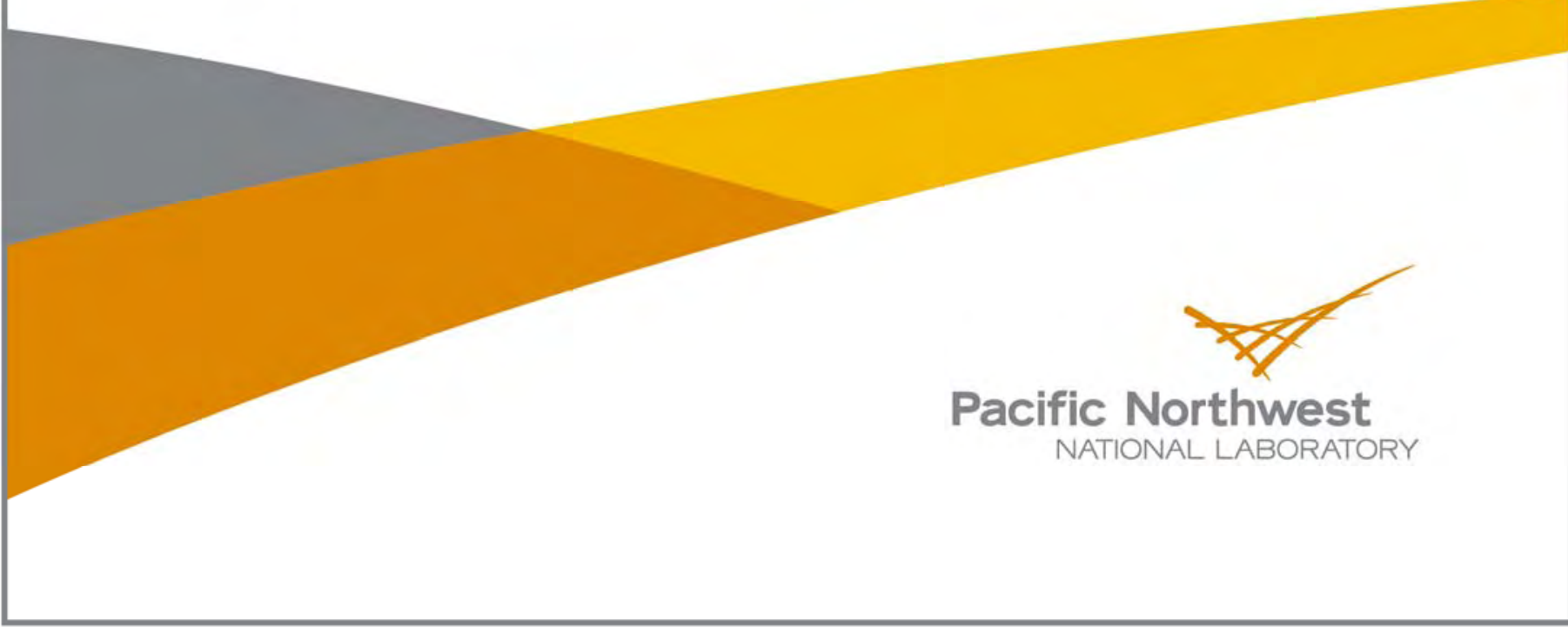




\title{
DISCLAIMER
}

This report was prepared as an account of work sponsored by an agency of the United States Government. Neither the United States Government nor any agency thereof, nor Battelle Memorial Institute, nor any of their employees, makes any warranty, express or implied, or assumes any legal liability or responsibility for the accuracy, completeness, or usefulness of any information, apparatus, product, or process disclosed, or represents that its use would not infringe privately owned rights. Reference herein to any specific commercial product, process, or service by trade name, trademark, manufacturer, or otherwise does not necessarily constitute or imply its endorsement, recommendation, or favoring by the United States Government or any agency thereof, or Battelle Memorial Institute. The views and opinions of authors expressed herein do not necessarily state or reflect those of the United States Government or any agency thereof.

\author{
PACIFIC NORTHWEST NATIONAL LABORATORY \\ operated by \\ BATTELLE \\ for the \\ UNITED STATES DEPARTMENT OF ENERGY \\ under Contract DE-AC05-76RL01830
}

Printed in the United States of America
Available to DOE and DOE contractors from the Office of Scientific and Technical Information,
P.O. Box 62, Oak Ridge, TN 37831-0062;
ph: (865) 576-8401
fax: $(865) 576-5728$
email: reports@adonis.osti.gov

\footnotetext{
Available to the public from the National Technical Information Service, U.S. Department of Commerce, 5285 Port Royal Rd., Springfield, VA 22161 ph: (800) 553-6847 fax: $(703) 605-6900$ email: orders@ntis.fedworld.gov online ordering: http://www.ntis.gov/ordering.htm
}

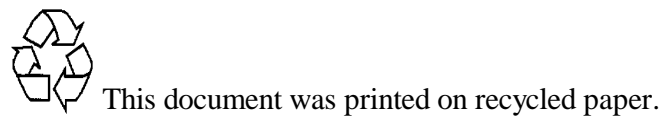




\title{
A Review of Subsurface Behavior of Plutonium and Americium at the 200-PW-1/3/6 Operable Units
}

Letter Report

\author{
K. J. Cantrell \\ R. G. Riley
}

January 2008

Prepared for Fluor Hanford, Inc. and the U.S. Department of Energy

under Contract DE-AC05-76RL01830

Pacific Northwest National Laboratory

Richland, Washington 99352 


\section{Contents}

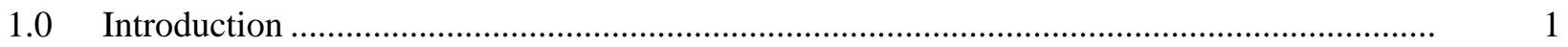

2.0 Brief Summary of the History and Current Status of the 200-PW-1/3/6 Operable Units ....... 1

3.0 Conceptual Models of Plutonium and Americium Transport at the 200-PW-1/3/6 Operable

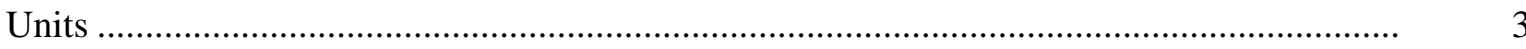

3.1 Plutonium/Americium Migration During Artificial Recharge Conditions.................... 4

3.2 Plutonium/Americium Migration at the 216-Z-9 Trench and 216-Z-1A Tile Field Under Conditions of Natural Recharge ........................................................................... 6

4.0 Important Data Gaps and Information Needs........................................................... 9

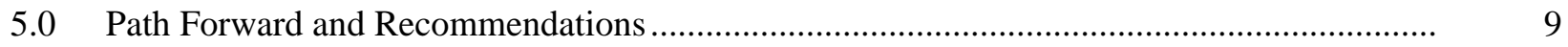

5.1 Determine Plutonium, Americium, and Co-Contaminant Sediment Compositions....... 10

5.2 Determinee Sediment/Contaminant Phase Associations by Scanning Electron Microscopy/Electron Dispersive Spectroscopy …….................................................. $\quad 10$

5.3 Determine Water-Leachable Components ................................................................. 10

5.4 Determine the Presence of Colloids in Aqueous Leachates of Sediments ................... 10

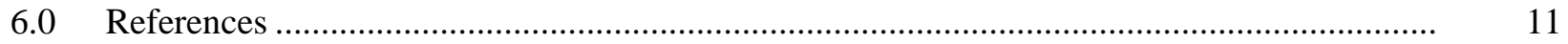

Appendix A - Background and Available Characterization Data for the 200-PW-1/3/6 Operable Units

Appendix B - Geologic Description of the 200-PW-1/3/6 Operable Units

B.1

Appendix C - Geochemistry of Plutonium and Americium

C.1

\section{Figures}

3.1 Conceptual Model of Past Plutonium and Americium Migration Beneath the 216-Z-9 Trench

3.2 Chemical Structures of the Oily Organic Co-Contaminants of Interest and the Degradation Products ofTributyl Phosphate

\section{Tables}

2.1 Summary of Key Waste Site Features for Two Representative High-Impact Waste Sites of the 200-PW-1/3/6 Operable Units

3.1 Co-Contaminant Properties and Influence on Plutonium/Americium Mobility in the Hanford Subsurface. 


\subsection{Introduction}

A common perception is that $\mathrm{Pu}$, based on its insolubility and strong sorptive behavior toward Hanford sediment, is not very mobile under typical Hanford Site subsurface conditions. However, remedial investigations conducted within the Hanford Site 200-PW-1/3/6 operable units have determined that, in one case, significant $\mathrm{Pu}$ and Am have moved to depths of up to $150 \mathrm{ft}$ below ground surface.

Fluor Hanford, Inc., requested that Pacific Northwest National Laboratory (PNNL) review available information and data pertaining to $\mathrm{Pu}$ and americium mobility in the subsurface at Hanford, with emphasis on vadose zone contamination within the 200-PW-1/3/6 operable units, to address this inconsistency between perception and data. In response to this request, PNNL compiled, analyzed, and summarized information and data on relevant waste site structures and associated subsurface geologies, waste composition and disposal histories, $\mathrm{Pu}$ and americium subsurface geochemistry, and contaminant characterization underlying key operable unit waste sites. Summarized information and data were used to develop a conceptual model that attempts to explain historical $\mathrm{Pu}$ and americium distributions in the subsurface and their potential for future migration based on current vadose zone characteristics in the 200-PW-1/3/6 operable units. Technical data gaps and information needs for refinement of the conceptual model were identified.

This report begins with a brief summary of the history and current status of 200-PW-1/3/6 operable units in Section 2. This is followed by a description of the PNNL conceptual model of Pu/Am migration at the 200-PW-1/3/6 operable units, during conditions of both past artificial recharge and current natural recharge (Section 3). Section 4 discusses data gaps and information needs. Section 5 provides recommendations for further work to address the data gaps and information needs identified in Section 4. A more detailed account of the waste disposal history, chemistry, and available characterization data for the 200-PW-1/3/6 operable units is presented in Appendix A. A summary geologic description of the 200-PW-1/3/6 operable units is presented in Appendix B. A brief discussion of the environmental geochemistry of $\mathrm{Pu}$ and $\mathrm{Am}$ is presented in Appendix $\mathrm{C}$.

\subsection{History and Current Status of 200-PW-1/3/6 Operable Units}

This section briefly summarizes the history and current status of the $200-\mathrm{PW}-1 / 3 / 6$ operable units. A more detailed account of the waste disposal history, chemistry, and summary of available characterization data for the 200-PW-1/3/6 operable units is presented in Appendix A.

The Plutonium/Organic-Rich Group Operable Unit (OU) waste sites are in the 200 East and 200 West Areas near the center of the Hanford Site in south-central Washington State. The Plutonium/OrganicRich Group OU includes three OUs where liquid wastes were disposed of into cribs, French drains, trenches, an injection/reverse well, settling tanks, drain/tile fields, and at an unplanned release site. The three OUs are the 200-PW-1 OU, the 200-PW-3 OU, and the 200-PW-6 OU. The 200-PW-1 OU waste sites primarily received $\mathrm{Pu}$ - and organic-rich wastes (mostly carbon tetrachloride, tributyl phosphate [TBP], and lard oil) from processes within the Z Plant Complex (now referred to as the Plutonium Finishing Plant [PFP] complex). The 200-PW-3 OU waste sites received organic-rich wastes (primarily refined kerosene [normal paraffin hydrocarbon (NPH)], TBP, and butanol) from the A Plant (PlutoniumUranium Extraction [PUREX] process). The 200-PW-6 OU waste sites received Pu-rich wastes from the 
PFP complex but did not receive organic-rich wastes from that complex. Both the 200-PW-1 and 200PW-6 OU waste sites are in the 200 West Area. The 200-PW-3 OU waste sites are $n$ the 200 East Area.

Based upon analysis of the various sites within the 200-PW-1/3/6 OUs, it has been determined that the waste sites can be classified into two major categories based primarily upon the type of wastes that were received by the waste site. The first waste site category received low-salt near-neutral waste sites. Plutonium and Am solubility in this type of waste is expected to be low, and adsorption is expected to be high (Cantrell et al. 2003). Characterization results are consistent with these expectations (DOE/RL 2007). The second waste site group is categorized as acidic high-salt waste with organic complexants. Plutonium and Am solubility in this type of waste is expected to be relatively high, and adsorption is expected to be relatively low (Cantrell et al. 2003).

Table 2.1 summarizes key features important to understanding the migration behavior of $\mathrm{Pu}$ and $\mathrm{Am}$ for two representative sites during artificial recharge conditions. The 216-Z-12 Crib is representative of low-salt near-neutral waste sites. Sites with waste of this nature experienced little migration of $\mathrm{Pu}$ and americium away from the point of discharge during artificial recharge conditions. This conclusion is based on the fact that maximum concentrations of Pu and Am occurred just below the disposal point and decreased rapidly with distance from the bottom of the crib. This occurred despite the huge volumes of waste (281 million L) being disposed in the trench.

In contrast, the average volumetric flux rate to the 216-Z-9 Trench was approximately one-tenth of the volumetric flux rate to the 216-Z-12 Crib, yet contamination at this site reached more deeply into the subsurface than what is observed at the 216-Z-12 Crib. The differences in depths of contaminant migration can be attributed to differences in the physical/chemical properties of the wastes disposed at each of these sites. Unlike the low-salt near-neutral waste discharged at the 216-Z-12 Crib, the liquid waste discharged to the 216-Z-9 Trench was highly acidic and contained organic complexants. The highly acidic waste disposed to the 216-Z-9 Trench moved down through the soil profile and, over time, consumed the buffering capacity of the underlying sediment. Loss of sediment buffering capacity allowed highly acidic subsurface conditions to prevail as waste discharging continued over a seven-year period. As a result of the high subsurface acidity and presence of organic complexants, conditions existed for enhanced $\mathrm{Pu}$ and americium migration (i.e., higher solubility in pore water and reduced sorption to sediment).

Most of the waste sites within the 200-PW-1/3/6 OUs received wastes that had the same general characteristics of those received by one of the two representative waste sites presented in Table 2.1. For example, the characteristics of the waste disposed to the 216-A-1A Tile Field were similar to those disposed in the 216-Z-9 Trench. The footprint 216-A-1A Tile Field $\left(2,370 \mathrm{~m}^{2}\right)$ is considerably larger than that of the 216-Z-9 Trench $\left(162 \mathrm{~m}^{2}\right)$, and the volumetric flux rate was about one-third that of the 216-Z-9 Trench $\left(1,310 \mathrm{~L} / \mathrm{m}^{2}-\mathrm{yr}\right)$. These characteristics were likely the primary reason that wastes disposed to the 216-Z-1A Tile Field did not reach saturate, and spread horizontally along the Cold Creek unit as occurred below the 216-Z-9 Trench. 
Table 2.1. Summary of Key Waste Site Features for Two Representative High-Impact Waste Sites of the 200-PW-1/3/6 Operable Units

\begin{tabular}{|l|l|l||}
\hline \multicolumn{1}{|c|}{ Waste Site } & \multicolumn{1}{c|}{$\begin{array}{c}\text { 216-Z-12 } \\
\text { Crib }\end{array}$} & \multicolumn{1}{c|}{$\begin{array}{c}\text { 216-Z-9 } \\
\text { Trench }\end{array}$} \\
\hline \hline Waste category & Low-salt near-neutral & Acidic high-salt, organic/rich \\
\hline Waste volume $(\mathrm{L})$ & $281,000,000$ & $4,090,000$ \\
\hline Footprint $\left(\mathrm{m}^{2}\right)$ & 546 & 162 \\
\hline Duration $($ years $)$ & 14 & 7 \\
\hline Average volumetric flux rate $\left(\mathrm{L} / \mathrm{m}^{2}\right.$-yr $)$ & 36,800 & 3,610 \\
\hline pH of infiltrating waste & $8-10$ & 2 \\
\hline Co-contaminants & nitrate, fluoride & $\begin{array}{l}\mathrm{CCl}_{4}, \mathrm{TBP}, \mathrm{DBBP}, \mathrm{DBP}, \mathrm{MBP}, \\
\text { lard oil, nitrate }\end{array}$ \\
\hline Pu - total mass disposed $(\mathrm{kg})$ & & $50-140$ \\
\hline
\end{tabular}

The characteristics of the waste disposed to the 216-Z-18 Crib were similar to those disposed in the 216-A-1A Tile Field. The footprint of the 216-Z-18 Crib $\left(7,505 \mathrm{~m}^{2}\right)$ is considerably larger than that of the 216-A-1A Tile Field. As a result, the volumetric flux rate was relatively low $\left(133 \mathrm{~L} / \mathrm{m}^{2}\right.$-yr). These were likely the primary reasons that significant Pu contamination below the 216-Z-18 Crib reached only relatively shallow depths (approximately $60 \mathrm{ft}$ below ground surface (bgs) compared to the 216-Z-9 Trench (120 ft bgs) or the 216-A-1A Tile Field (110 ft bgs).

Plutonium contamination beneath the $216-\mathrm{A}-8 \mathrm{Crib}$ is relatively minor. The maximum concentration of $\mathrm{Pu}$ measured at this site was $55.7 \mathrm{pCi} / \mathrm{g}$ at 19 to $21.5 \mathrm{ft}$ bgs (Borehole C4545). The bottom of the crib varied from 16 to $19 \mathrm{ft}$ bgs, indicating that adsorption of Pu to the underlying sediments occurred rapidly just below the crib. The vapor condensate wastes received by the 216-A-8 Crib were relatively dilute aqueous solutions containing relatively low concentrations of contaminants. Plutonium in such solutions would be expected to adsorb strongly to Hanford sediments, based upon high $\mathrm{K}_{\mathrm{d}}$ values measured in dilute solutions. The situations for the 216-Z-8 French Drain and 216-Z-10 Injection/Reverse Well are similar to that of the 216-A-8 Crib, with strong adsorption of the minor amounts of $\mathrm{Pu}$ disposed to these facilities.

\subsection{Conceptual Models of Plutonium and Americium Transport at the 200-PW-1/3/6 Operable Units}

Based on historical data (see Appendix A for more details), it was determined that four of the six representative waste sites in the 200-PW-1/3/6 operable units received liquid waste effluents contaminated with $\mathrm{Pu}$ and americium just below the ground surface during the years 1955 through 1985. The duration of active disposal to each of these sites varied from a low of 7 years for two of the sites (216-Z-9 Trench and 216-Z-8 French Drain) to a high of 30 years for the 216-A-8 Crib. The active disposal period for the 216-Z-1A Tile Field was intermediate at 15 years. Downward migration of Pu and americium was influenced by the artificial recharge conditions that existed during those time frames. As each waste site was retired (i.e., when artificial recharge ceased), the subsurface environment underlying each of these waste sites drained and was restored to conditions influenced by the natural recharge 
conditions assumed to be present at this time. Post-operational times as of today are 45 years for the 216-Z-9 Trench and 216-Z-8 French Drain, 38 years for the 216-Z-1A Tile Field and 22 years for the 216-A-8 Crib.

\subsection{Plutonium/Americium Migration During Artificial Recharge Conditions}

Figure 3.1 depicts a conceptual model of contaminant distribution and subsurface conditions underlying the 216-Z-9 Trench during the post-operational period. Significant quantities of particulate $\mathrm{Pu}$ (Price and Ames 1975) were rapidly filtered out of the acidic waste during the operational period and reside in the sediments near the disposal point underlying the trench. Previous data analysis (Appendix A) indicates that the majority of the Pu and Am dissolved in liquid wastes was concentrated in a silt layer at a depth of $65 \mathrm{ft}$ bgs within the Hanford formation and the Cold Creek unit underlying the trench (see Appendix B for details of the geologic setting within the 200-PW-1/3/6 OUs). Plutonium, Am, and co-contaminants also are spread laterally along the top of the silt layer at $65 \mathrm{ft}$ bgs. Tributyl phosphate (TBP) appears to have been attenuated in this layer, and Pu appears to be preferentially attenuated relative to Am (i.e., more Pu appears to be accumulate in that layer than Am). Dibutyl butyl phosphonate (DBBP) and TBP degradation products (i.e., dibutyl [DBP]- and monobutylphosphate [MBP]) also may be present in the silt layer at $65 \mathrm{ft}$ bgs; however, data for these compounds are not currently available. The $\mathrm{pH}$ of this silt layer is acidic (ranging from approximately 4 to 7 ), likely due to the loss of buffering capacity during the operational period and inability of these sediments to recover. The limited buffering capacity of the silt layer allowed the highly acidic salt waste to pass through the layer and continue its downward migration to the Cold Creek unit. Some of the highly acidic salt waste has likely spread along the top of the Cold Creek unit. The composition of this waste is likely different compared to the waste that spread laterally along the top of the upper silt layer at $65 \mathrm{ft}$ bgs (i.e., little or no organo-phosphate co-contaminants or lard oil with lower concentrations of $\mathrm{Pu}$ and comparable levels of Am). Due to their higher aqueous solubility (i.e., relative to TBP), TBP degradation products (DBP and MBP) are likely present in the laterally spread waste and in the upper portion of the Cold Creek unit. The $\mathrm{pH}$ of the Cold Creek unit appears to be somewhat below to slightly above neutral. Both Pu and Am are attenuated in the Cold Creek unit layer. The acid components of the waste that reached the caliche layer appear to have been effectively neutralized by carbonate, based on the detection of elevated levels of nitrate in this layer. Dibutyl phosphate and MBP contacting this layer may have been neutralized.

No significant waste impacts below the Cold Creek unit have been detected. Only trace levels of $\mathrm{Pu}$ and Am were detected in the sediment directly below the Cold Creek unit in the Ringold Formation. The trace levels of $\mathrm{Pu}$ and Am detected below the Cold Creek unit are likely the result of contaminants being spread to lower depths during the drilling operation. The $\mathrm{pH}$ below the Cold Creek unit was in the range of 8 to 9.5 .

This model indicates that no preferential flow paths are required to explain the $\mathrm{Pu}$ and $\mathrm{Am}$ contamination found at depth beneath the 216-Z-9 Trench. The Pu and Am found in the vadose zone to $120 \mathrm{ft}$ bgs were the result of simple vertical advective flow of waste solutions contaminated with Pu and Am disposed to the trench. Preferential flow paths such as clastic dikes or enhanced migration as a result of colloidal transport are not expected to have had a significant impact on the transport of $\mathrm{Pu}$ and Am within the context of the outlined conceptual model for artificial recharge conditions. 


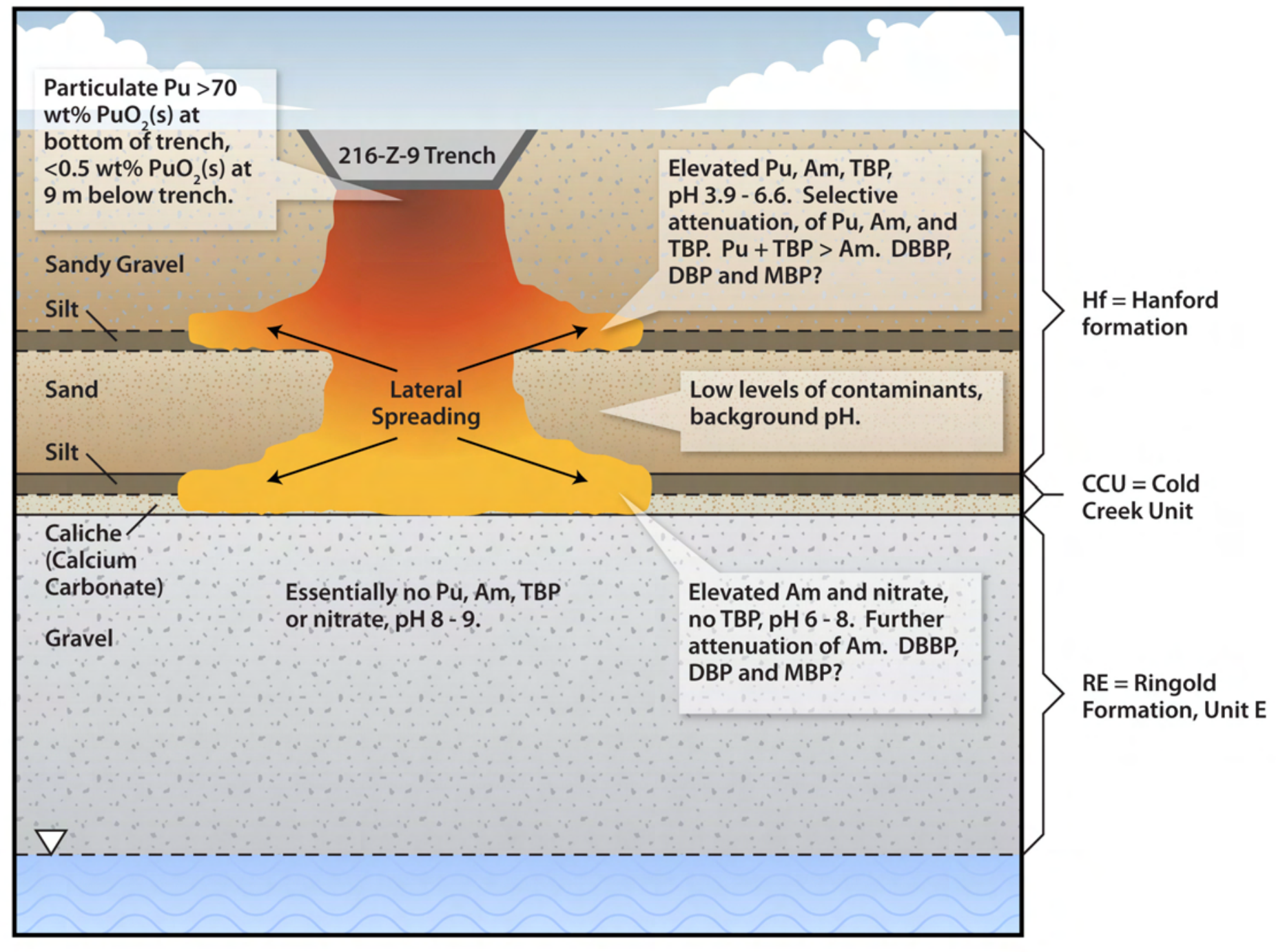

Figure 3.1. Conceptual Model of Past Plutonium and Americium Migration Beneath the 216-Z-9 Trench 


\subsection{Plutonium/Americium Migration at the 216-Z-9 Trench and 216-Z-1A Tile Field Under Conditions of Natural Recharge}

The conceptual model for discharge under artificial recharge conditions has shown $\mathrm{Pu}$ and $\mathrm{Am}$ to be attenuated in silt layers underlying the 216-Z-9 trench. Organic co-contaminants are present with $\mathrm{Pu}$ and Am in the silt layer at $65 \mathrm{ft}$ bgs, while Am appears to be the predominant attenuated contaminant in the silt layer component of the Cold Creek unit. Dibutyl phosphate, one of the degradation products of TBP, is suggested to be stable in water at $\mathrm{pH}$ values of 4.0, 7.0, and 9.0, and have relatively long lifetimes in the environment (OECD SIDS 1994). This would suggest the potential presence of DBP and MBP in both silt layers. Since cessation of artificial recharge 45 years ago, reaction has occurred between $\mathrm{Pu}$, Am, co-contaminants, degradation products of TBP, and the subsurface sediments (aging process), whose initial physical/chemical properties were altered (loss of buffering capacity) as a result of continuous contact with highly acidic, high-salt waste and coating of the particles by oily co-contaminants (i.e., lard oil, TBP, and DBBP). The aging process occurred during a gradual return to natural recharge conditions. Characterization data suggest that significant migration downward from these silt layers has not occurred since cessation of artificial recharge under the 216-Z-9 Trench (Appendix A).

Figure 3.2 shows the chemical structures of the oily organic co-contaminants of interest and the degradation products of TBP. The oily co-contaminants are hydrophobic and considered to be slightly soluble in water. Because of their hydrophobicity, they would tend to show a higher affinity for the sediment phase as opposed to the water phase. The degradation products of TBP are a factor of 10 greater in solubility than their hydrophobic counterparts. The octanol/water partition coefficient $\left(\mathrm{P}_{\text {ow }}\right)$ for DBP has been estimated at 0.57 (OECD SIDS 1994). The low value of $\mathrm{P}_{\text {ow }}$ coupled with higher water solubilities suggest that DBP and MBP have a lower affinity for sediment than their oily co-contaminant counterparts. While this may be the case for sediment particles that were not coated with oily cocontaminants, it may not be the case for coated sediment particles. Application of a generic fugacity model to DBP has indicated that when released into water, most of this chemical is likely to be distributed into soil and sediment (OECD SIDS 1994). Concentrations of oily co-contaminants transported in sediment pore water would be lower than those expected for TBP degradation products DBP and MBP. The structure of lard oil prohibits it from being a candidate for complexation with $\mathrm{Pu}$ or Am. Plutonium and Am are known to form coordination complexes with TBP and DBBP, but such complexes, being non-ionic, are not likely to be stable in subsurface sediments. In contrast, the free hydroxyl groups in the structures of DBP and MBP could potentially form ionic complexes with Pu and Am (Table 3.1).

Release of $\mathrm{Pu}$ and Am from these silt layer source terms is dependent on their relationship to sediment particle composition. One possibility is that they are sorbed to particles with surface coatings of the oily co-contaminants. Release would involve Pu or Am diffusion to the particle surface and subsequent release to migrating pore water. The magnitude of release would be dependent on the magnitude of partitioning of complexed (e.g., with DBP or MBP) or un-complexed Pu or Am species. The effect of potential DBP or MBP complexation on the magnitude of Pu and Am partition coefficients is unknown. At the other extreme are particles that escaped coating by oily co-contaminants and whose mineralogical composition has been altered due by continuous contact with the acidic waste. In this case, $\mathrm{Pu}$ and $\mathrm{Am}$ may be incorporated into the altered mineral solid phases. Release of $\mathrm{Pu}$ and Am would result from dissolution from precipitated solid phases. 

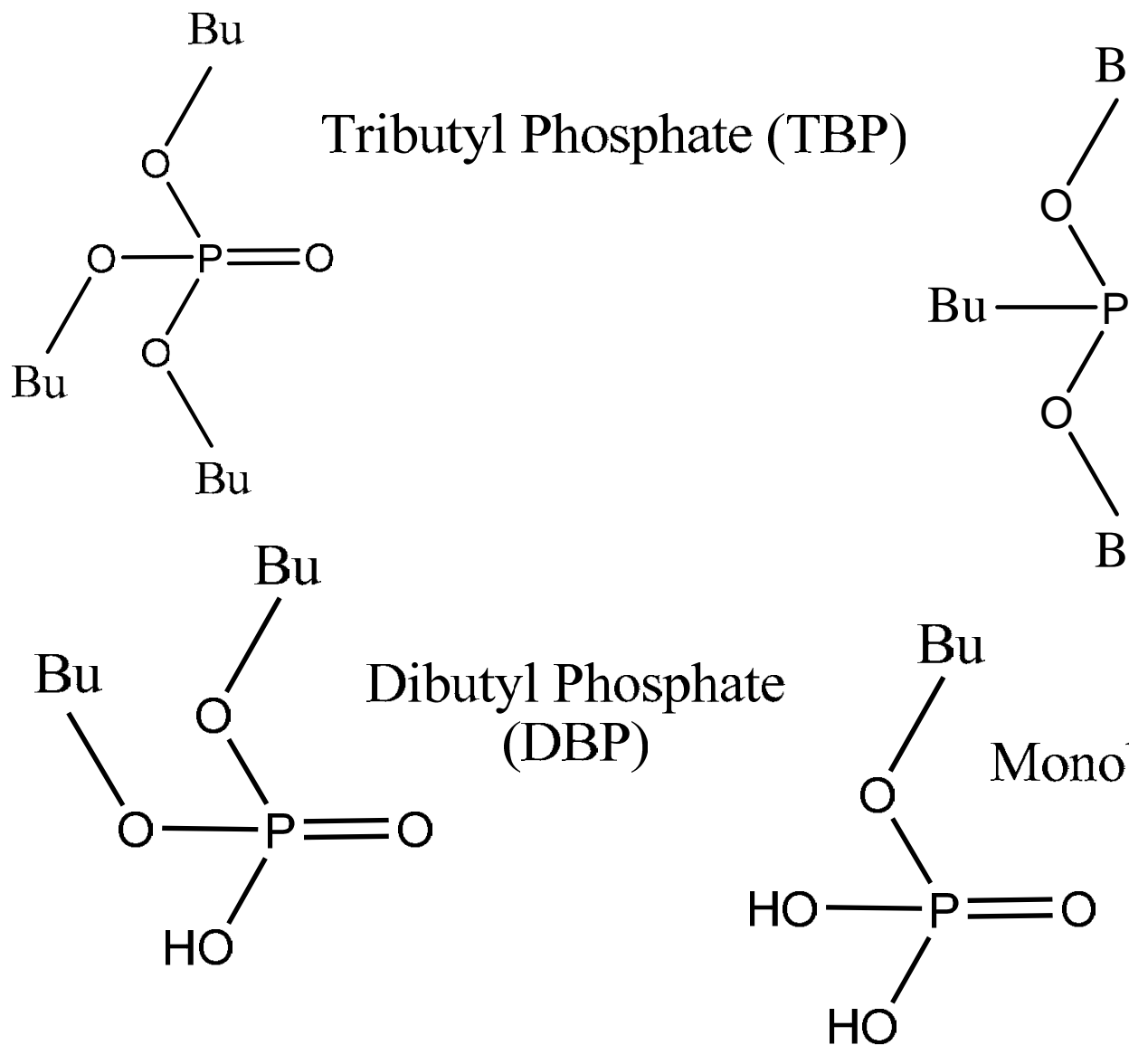

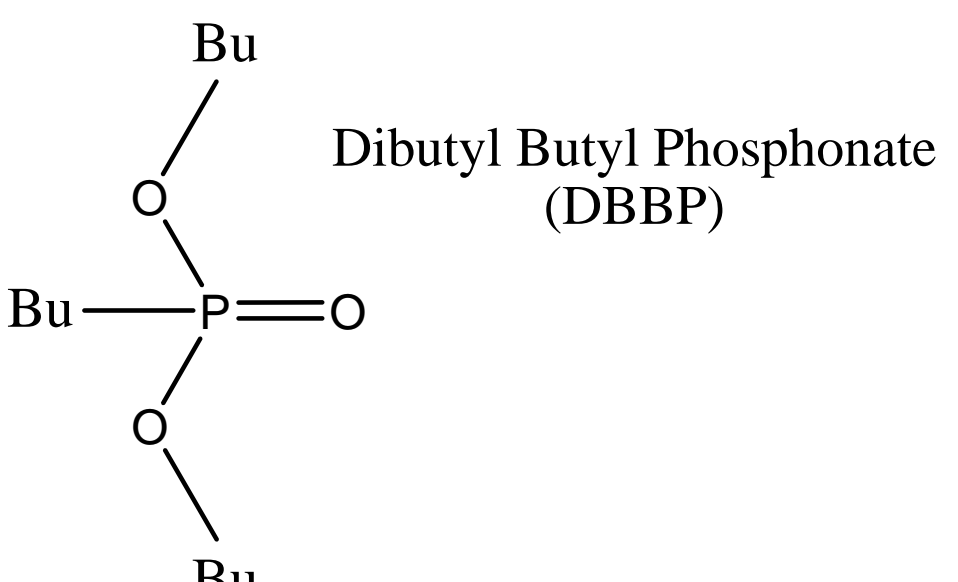

$\mathrm{Bu}$

$\mathrm{Bu}$ indicates butyl group

$$
\mathrm{CH}_{3}\left(\mathrm{CH}_{2}\right)_{3}-
$$

Lard oil - glycerol fatty acid esters $\mathrm{R}=$ fatty acid in the $\mathrm{C}_{16}$ to $\mathrm{C}_{18}$ range

Figure 3.2. Chemical Structures of the Oily Organic Co-Contaminants of Interest and the Degradation Products of TBP 
Table 3.1. Co-Contaminant Properties and Influence on Plutonium/Americium Mobility in the Hanford Subsurface

\begin{tabular}{|c|c|c|c|c|}
\hline Co-Contaminant & $\begin{array}{l}\text { Solubility in Water } \\
\text { (g/L) }\end{array}$ & $\begin{array}{c}\text { Complexation } \\
\text { Potential in } \\
\text { Pore Water }\end{array}$ & $\begin{array}{l}\text { Co-Contaminant } \\
\text { Mobility in } \\
\text { Pore Water }\end{array}$ & Effect on Pu/Am Migration \\
\hline Lard Oil & $\begin{array}{c}\text { slightly soluble }{ }^{1} \\
\sim 0.7-1.4\end{array}$ & none $^{3}$ & low $^{6}$ & Sequestration medium $^{8}$ \\
\hline TBP & $\begin{array}{c}\text { slightly soluble }^{1} \\
0.39\end{array}$ & low to none ${ }^{4}$ & low $^{6}$ & Sequestration medium $^{8}$ \\
\hline DBBP & $\begin{array}{c}\text { slightly soluble }^{1} \\
0.5\end{array}$ & low to none ${ }^{4}$ & low $^{6}$ & Sequestration medium $^{8}$ \\
\hline DBP & $\begin{array}{c}\text { soluble }^{2} \\
17-18\end{array}$ & high? $?^{5}$ & $\operatorname{high}^{7}$ & Increase or decrease in mobility ${ }^{9}$ \\
\hline MBP & of high solubility ${ }^{2}$ & high? ${ }^{5}$ & high $^{8}$ & Increase or decrease in mobility ${ }^{9}$ \\
\hline $\begin{array}{l}{ }^{1} \text { Lard oil solubility } \\
{ }^{2} \text { DPB solubility fro } \\
\text { solubility in water tl } \\
{ }^{3} \text { Lard oil is a compl } \\
\text { this material prohibi } \\
{ }^{4} \text { Carefully controlle } \\
\text { important to Pu and } \\
\text { process waste dispo } \\
{ }^{5} \text { The hydroxyl grou } \\
\text { potentially soluble i } \\
{ }^{6} \text { Because of low sol } \\
\text { are low. } \\
{ }^{7} \text { DBP and MBP are } \\
{ }^{8} \text { Complexed and un } \\
\text { release from sedime } \\
\text { partitioning betweer } \\
{ }_{9}^{9} \text { Plutonium and Am } \\
\text { coated with oily co- } \\
\text { coated with oily co- }\end{array}$ & $\begin{array}{l}\text { om Kirk-Othmer (1980 } \\
\text { OECD SIDS (1994). } \\
\text { n DBP. } \\
\text { x mixture of fatty acid } \\
\text { them from forming col } \\
\text { conditions in the RECL } \\
\text { m recovery. Condition } \\
\text { on DBP and MBP hav } \\
\text { pore water. } \\
\text { bility and their affinity } \\
\text { ighly soluble in pore w } \\
\text { omplexed Pu and Am m } \\
\text { ts into migrating pore } \mathrm{w} \\
\text { he sediment surface an } \\
\text { omplexation with DBP } \\
\text { ontaminants. It is not kı } \\
\text { ontaminants. }\end{array}$ & $\begin{array}{l}\text { TBP and DBBP s } \\
\text { sed on its increase } \\
\text { ers of glycerol. Th } \\
\text { lexes with Pu or A } \\
\text { LEX process allov } \\
\text { tre not conducive t } \\
\text { he potential to for } \\
\text { sediment, amount } \\
\text { r (partitioning sho } \\
\text { be sequestered in } \\
\text { er is likely controll } \\
\text { ore water. } \\
\text { ould alter the diffu } \\
\text { wn how such comr }\end{array}$ & $\begin{array}{l}\text { bility from Burger ar } \\
\text { olarity relative to DF } \\
\text { absence of ionic char } \\
\text { f formation of coordi } \\
\text { hese complexes bein } \\
\text { stable ionic complex } \\
\text { f lard oil, DBP, and } \\
\text { ly co-contaminants c } \\
\text { by diffusion in the o } \\
\text { onal and partitioning } \\
\text { xation would affect } \mathrm{F}\end{array}$ & $\begin{array}{l}\text { Wagner (1958). } \\
\text { P, MBP is expected to have a higher } \\
\text { cteristics to compounds comprising } \\
\text { hation complexes with TBP and DBBP } \\
\text { stable in the subsurface subsequent to } \\
\text { with Pu and Am that would be } \\
\text { BBP likely to migrate in pore water } \\
\text { ly coating and the magnitude of } \\
\text { ated on sediment particles. Their } \\
\text { a and Am release rates from sediments }\end{array}$ \\
\hline
\end{tabular}

There is also the potential for colloidal transport of $\mathrm{Pu}$ and Am under unsaturated conditions. Several studies of colloid transport of highly sorptive radionuclide contaminants including $\mathrm{Pu}$ and $\mathrm{Cs}$ have been conducted at Hanford (Flury et al. 2002; Cherrey et al. 2003; Zhuang et al. 2003, 2004; Marshal et al. 2004; Dai et al. 2005; Chen and Flury 2005; Chen et al. 2005; Czigany et al. 2005). These studies indicate that colloidal transport of highly sorptive radionuclides is unlikely to be important at Hanford unless water contents and flow rates are locally and temporally increased by snowmelt or episodic artificial recharge (Czigany et al. 2005). Other work has shown a significant decrease in colloid mobility at a volumetric water content approximating the degree of saturation in Hanford vadose sediments (i.e., $6 \%$ ). The reduction in mobility was attributed to a reduction in mobility related to the diameter of colloidal material and water film thickness (McGrail and Kaplan 1997).

Estimated long-term drainage rates through the vadose zone resulting from natural infiltration for use in Hanford assessments (Last et al. 2006; Fayer and Keller 2007) indicate that a worst-case rate (denuded gravel surface) of less than $100 \mathrm{~mm} / \mathrm{yr}$ could be expected. If the site were to be vegetated with natural shrubs, a drainage rate of $5.0 \mathrm{~mm} / \mathrm{yr}$ or less could be expected, and if a modified RCRA C barrier were 
placed above the site, a drainage rate of $0.1 \mathrm{~mm} / \mathrm{yr}$ could be expected. This range of low drainage rates suggests that the current driving force for transport of dissolved and/or colloidal Pu or Am is minimal.

\subsection{Important Data Gaps and Information Needs}

The discussion in Section 3.2 suggests important data and information gaps in the conceptual model for understanding the future migration potential for Pu and Am away from the silt layer at $65 \mathrm{ft}$ bgs and the Cold Creek unit in the vadose zone underlying the 216-Z-9 Trench. Data gaps identified and the relevant information provided for conceptual model refinement through experimental work are

- the absence of confirmatory data on the concomitant presence of TBP, DBBP, DBP, MBP, and lard oil in key subsurface sediments:

- Such data could provide insight on the extent to which co-contaminants have altered the surface properties of sediments.

- Understanding of such alterations is important to understanding adsorption behavior of Pu and Am on these sediments (i.e., values of $K_{d}$ ).

- The absence of data on co-leachability of Pu, Am, TBP, DBBP, DBP, and MBP and major ion chemistry in aqueous leachates of sediments.

- The observance of co-leachability would provide evidence for the presence of co-contaminant influence on $\mathrm{Pu} / \mathrm{Am}$ mobility (e.g., the possible occurrence of complexation).

- The extent of absence of leachable butyl phosphates would lend qualitative insight on the potential selective influence of butyl phosphate compounds on Pu/Am mobilization.

- Geochemical modeling of co-leachability data would provide insight on Pu/Am speciation present.

- the absence of data on the leachability of colloidal particles from contaminated sediments:

- Tests involving the leaching of contaminated sediments would provide information on the potential for colloidal transport under worst-case conditions (i.e., if significant concentrations of $\mathrm{Pu}$ or $\mathrm{Am}$ as colloids are not found to be released by this method, transport of $\mathrm{Pu}$ and $\mathrm{Am}$ via colloid migration is not likely to be important).

\subsection{Recommendations}

To address the data gaps identified in Section 4 and information needed for refinement of the current conceptual model, additional experimental work is recommended. Archived sediment samples from wells 299-W15-46 and 299-W15-48 would be selected for use. Recommended experimental work includes determination of 1) $\mathrm{Pu}, \mathrm{Am}$, and co-contaminants in sediments; 2) sediment/contaminant phase associations; 4) water-leachable components; and 5) colloid concentrations in sediment leachates. 


\subsection{Determine Plutonium, Americium, and Co-Contaminant Sediment Compositions}

The concentrations of contaminants of concern $\left({ }^{239 / 240} \mathrm{Pu}\right.$ and $\left.{ }^{241} \mathrm{Am}\right)$, important co-contaminants (TBP, DBBP, lard oil), and degradation products of TBP (i.e., DBP, and MBP) will be determined in selected sediment samples. Total ${ }^{239 / 240} \mathrm{Pu}$ and ${ }^{241} \mathrm{Am}$ will be determined using a microwave acid digestion procedure. TBP, DBBP, DBP, and MBP will be determined from the analysis of sequential extracts of sediments by gas chromatography/mass spectrometry.

\subsection{Determination of Sediment/Contaminant Phase Associations by Scanning Electron Microscopy/Energy Dispersive Spectroscopy}

Scanning electron microscopy (SEM) with an energy dispersive spectroscopy (EDS) system will be applied to select samples to obtain high-resolution images of the morphologies, sizes, surface textures, and composition of micrometer/submicrometer-sized particles present in the sediment samples. This technique is particularly useful for determining elemental composition of particles containing $\mathrm{Pu}$ and $\mathrm{Am}$ and phase associations of the $\mathrm{Pu}$ and $\mathrm{Am}$. The information collected with this method will help to verify the form of $\mathrm{Pu}$ and $\mathrm{Am}$ in the contaminated sediments and any possible associations with organophosphate compounds.

\subsection{Determine Water-Leachable Components}

A series of water extractions will be performed to determine the leachability of ${ }^{239 / 240} \mathrm{Pu}$ and ${ }^{241} \mathrm{Am}$ from selected sediments and to determine the speciation of the leachable ${ }^{239 / 240} \mathrm{Pu}$ and ${ }^{241} \mathrm{Am}$. Water extracts of the sediments will be analyzed for ${ }^{239 / 240} \mathrm{Pu}$ and ${ }^{241} \mathrm{Am}, \mathrm{pH}$, alkalinity, and major cations and anions. Solvent extracts of the water extracts will be analyzed for TBP, DBBP, and derivatized forms of DBP and MBP). These experiments will provide speciation information critical to understanding the future migration potential for $\mathrm{Pu}$ and $\mathrm{Am}$. This information will be used also to conduct geochemical modeling, which may provide insight to identify potential solubility-controlling phases and to provide empirical desorption $\mathrm{K}_{\mathrm{d}}$ values that can be used for transport-modeling purposes. The water extractions will be conducted in duplicate for each sample, with contact periods of 1 day and 1 week.

If significant concentrations of $\mathrm{Pu}$ and $\mathrm{Am}$ are found in the leachates from the contaminated sediments, then a set of adsorption experiments will be conducted on representative Ringold Formation sediments to determine empirical $\mathrm{K}_{\mathrm{d}}$ values.

\subsection{Determination of Colloid Concentrations in Aqueous Leachates of Sediments}

Batch experiments similar to those described in Section 5.3 will be performed to determine the potential for release of $\mathrm{Pu}$ - and Am-containing colloids from contaminated sediments. Sediment samples will be shaken in a tube overnight with Hanford groundwater. The sediment extracts will then be allowed to settle for a day. The subsequent supernatants will be sequentially filtered (i.e., through $0.45-\mu \mathrm{m}$ filters followed by $0.0018-\mu \mathrm{m}$ filters). Any Pu or Am that is not filtered out by the $0.45-\mu \mathrm{m}$ filter but filtered out by the $0.0018-\mu \mathrm{m}$ filters will be identified as colloidal material containing Pu and/or Am. 


\subsection{References}

Burger LL and RM Wagner. 1958. "Preparation and Properties of Some Organophosphorus Compounds." Industrial and Engineering Chemistry 3(2):310-313.

Cantrell KJ, RJ Serne, and GV Last. 2003. Hanford Contaminant Distribution Coefficient Database and Users Guide. PNNL-13895, Rev. 1, Pacific Northwest National Laboratory, Richland, Washington.

Chen $\mathrm{G}$ and M Flury. 2005. "Retention of mineral colloids in unsaturated porous media as related to their surface properties." Colloids Surface A: Physicochem. Eng. Aspects 256:207-216.

Chen G, M Flury, and JB Harsh. 2005. "Colloid-facilitated transport of cesium in variably saturated Hanford sediments." Environmental Science and Technology 39:3435-3442.

Cherrey KD, M Flury, and JB Harsh. 2003. "Nitrate and colloid transport through coarse Hanford sediments under steady state, variably saturated flow." Water Resources Research 39(6):1165-1174.

Czigany S., M Flury, and JB Harsh. 2005. "Colloid stability in vadose zone Hanford sediments." Environmental Science and Technology 39:1506-1512.

Dai M, KO Buesseler, and SM Pike. 2005. "Plutonium in groundwater at the 100K-Area of the U.S. DOE Hanford Site. Journal of Contaminant Hydrology 76:167-189.

DOE/RL. 2007. Remedial Investigation Report for the Plutonium/Organic-Rich Process Condensate/Process Waste Group Operable Unit: Includes the 200-PW-1, 200-PW-3, and 200-PW-6 Operable Units. DOE/RL-2006-51, Rev. 0, prepared for the U.S. Department of Energy, Richland, Washington.

Fayer MJ and JM Keller. 2007. Recharge Data Package for Hanford Single-Shell Tank Waste Management Areas. PNNL-16688, Pacific Northwest National Laboratory, Richland, Washington.

Flury M, JB Mathison, and JB Harsh. 2002. "In situ mobilization of colloids and transport of cesium in Hanford sediments.” Environmental Science and Technology 36:5335-5341.

Kirk-Othmer. 1980. Fats and Fatty Oils. Encyclopedia of Chemical Technology, Third Edition, Volume 9.John Wiley and Sons, New York, New York, p 808.

Last GV, EJ Freeman, KJ Cantrell, MJ Fayer, GW Gee, WE Nichols, BN Bjornstad, DG Horton. 2004. Vadose Zone Hydrogeology Data Package for the 2004 Composite Analysis. PNNL-14702, Rev. 0, Pacific Northwest National Laboratory, Richland, Washington.

Marshal K, JB Harsh, M Flury, AR Felmy, and H Zhao. 2004. "Colloid formation in Hanford sediments reacted with simulated tank waste.” Environmental Science and Technology 38:5750-5756.

McGraw MA and DI Kaplan. 1997. Colloid Suspension Stability and Transport Through Unsaturated Porous Media. PNNL-11565, Pacific Northwest National Laboratory, Richland, Washington. 
OECD SIDS. 1994. IPCS INCHEM - The International Programme on Chemical Safety. Screening Information Data Set (SIDS) for High Production Volume Chemicals: Dibutyl Phosphate. Accessed January 24, 2008 at http://www.inchem.org/documents/sids/sids/107-66-4.pdf

Zhuang J, M Flury, and Y Jin. 2003. "Colloid-facilitated Cs transport through water-saturated Hanford sediment and Ottawa sand.” Environmental Science and Technology 37:4905-4911.

Zhuang, J., Y. Jin, and M. Flury. 2004. "Comparison of Hanford colloids and kaolinite transport in porous media." Vadose Zone Journal 3:395-402. 


\section{Appendix A}

Background and Available Characterization Data for the 200-PW-1/3/6 Operable Units 


\section{Appendix A}

\section{Background and Available Characterization Data for the 200-PW-1/3/6 Operable Units}

The material in this appendix has been taken in large part from DOE/RL (2007).

\section{A.1 200-PW-1 Operable Unit Fuel Reprocessing Waste Disposal}

\section{A.1.1 216-Z-9 Trench Structure and Waste Disposal Practices}

The 216-Z-9 Trench is located in the 200 West Area, about $213 \mathrm{~m} \mathrm{(700} \mathrm{ft)} \mathrm{east} \mathrm{of} \mathrm{the} \mathrm{234-5Z}$ Building and $152 \mathrm{~m}(500 \mathrm{ft}$ ) south of 19th Street (Figure A.1). The 216-Z-9 Trench consists of a $6 \mathrm{~m}$ (20-ft)-deep excavation with a $37-$ by $27-\mathrm{m}$ (120- by $90-\mathrm{ft})$ concrete cover. The walls of the trench slope inward and downward to the 18- by $9-\mathrm{m}$ (60- by $30-\mathrm{ft})$ floor space, which had a slight slope to the south. The underside of the concrete cover was paved with acid-resistant brick/tiles. The cover of the trench is supported by six concrete columns.

From July 1955 through June 1962, the 216-Z-9 Trench received all solvent and aqueous wastes from the Recovery of Uranium and Plutonium by Extraction (RECUPLEX) process that operated in the 234-5Z Building (i.e., Z Plant). The two major liquid streams used in the RECUPLEX process were an aqueous stream composed of nitric and hydrofluoric acids to produce soluble plutonium as plutonium nitrate and an organic phase solvent extraction stream composed of carbon tetrachloride and TBP (85:15 ratio) or carbon tetrachloride and DBBP (50:50 ratio) to recover the plutonium or plutonium and americium from the aqueous streams. The process was used to recover plutonium from many different types of scrap or wastes, such as ingot and casing skulls (ingoting dross), slag, and crucible button line supernates. With exposure to ionizing radiation and nitric acid, the TBP in the solvent extraction stream gradually would degrade to dibutyl phosphate. Dibutyl phosphate DBP has a much greater affinity for plutonium than TBP and would not work in the process because of its poor stripping properties. The degraded solvent was periodically discharged batch-wise and replaced with fresh solvent. The DBBP solution was discharged after each use. The RECUPLEX waste solutions consisted of aluminum, magnesium, calcium, and other metal nitrate salt wastes; used solvents (15\% TBP (i.e., a mixture of TBP and DBP) or $50 \%$ dibutybutyl phosphonate (DBBP) in $\mathrm{CCl}_{4}$; other organic wastes such as solvent washings, fabrication oil (a mixture of lard oil and carbon tetrachloride $\left(\mathrm{CCl}_{4}\right)$ used as a cutting oil during the machining of plutonium) (Ridgway et al., 1971), and other deteriorated materials from hood and equipment flushes.

The 216-Z-9 Trench received approximately 4.1 million L (1.1 Mgal) of high-salt, acidic, aqueous, and organic liquid waste from the RECUPLEX process. Material discharged to the trench reportedly included 50 to $140 \mathrm{~kg} \mathrm{Pu}$ [3,600 to $11,000 \mathrm{Ci}^{239 / 240} \mathrm{Pu}$ (assuming $6 \%$ by wt. ${ }^{240} \mathrm{Pu}$, DOE/DP 1996)], $8,580 \mathrm{Ci}$ of ${ }^{241} \mathrm{Am}, 130,000$ to $480,000 \mathrm{~kg}$ (286,600 to 1,058,219 lb) of carbon tetrachloride, 9,300 L lard oil, and 500,000 kg (1,102,310 lb) of nitrate (DOE/RL 1992, Z Plant Source Aggregate Area Management Study Report; DOE/RL 1997, Waste Site Grouping for 200 Areas Soil Investigations). 


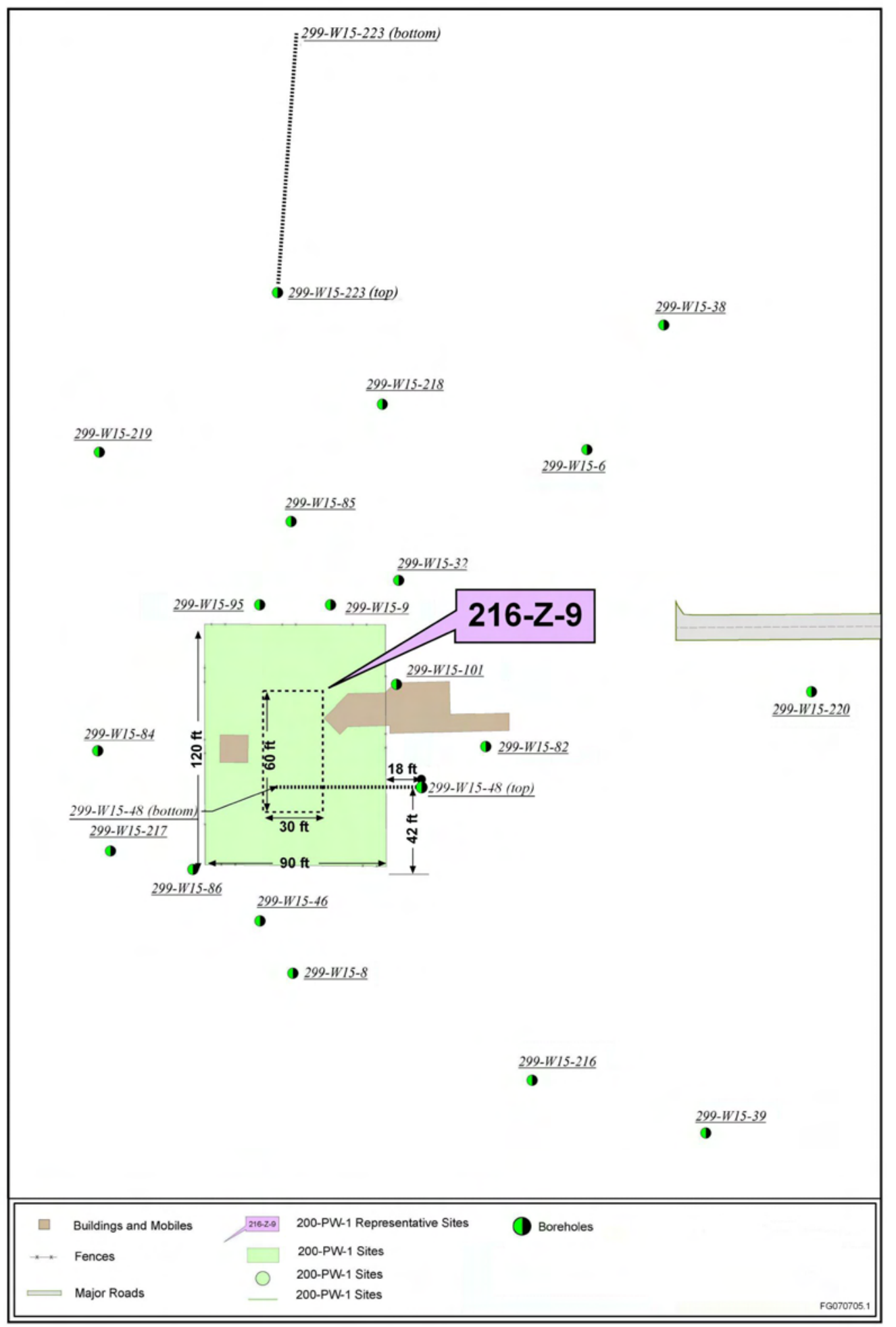

Figure A.1. Location of Wells Around the 216 Z 9 Trench

Mining took place at the 216-Z-9 Trench in 1976 and 1977, and plutonium was removed from the upper $0.3 \mathrm{~m}$ ( $1 \mathrm{ft}$ ) of soil from the floor of the trench. The mining operation removed an estimated $58 \mathrm{~kg}$ (128 lb) of plutonium, leaving an estimated $48 \mathrm{~kg}(106 \mathrm{lb})$ of plutonium in the trench (RHO 1978). 


\section{A.1.2 216-Z-1A Tile Field Structure and Waste Disposal Practices}

The 216-Z-1A Tile Field is located in the 200 West Area, about $153 \mathrm{~m} \mathrm{(500} \mathrm{ft)} \mathrm{south} \mathrm{of} \mathrm{the} \mathrm{234-5Z}$ Building and immediately south of the 216-Z-1 and 216-Z-2 Cribs and adjacent to the 216-Z-3 Crib (Figure A.1). The tile field piping consists of 20-cm (8-in.)-diameter perforated vitrified clay pipe placed on a $1.5-\mathrm{m}$ (5-ft)-deep gravel bed, $4 \mathrm{~m}(14 \mathrm{ft})$ bgs. The piping consists of a 79-m (260-ft)-long northsouth trunk or main pipeline with seven pairs of $21-\mathrm{m}(70-\mathrm{ft})$ laterals spaced at $11-\mathrm{m}(35-\mathrm{ft})$ intervals in a centered, herringbone pattern. The piping system was overlaid with $15 \mathrm{~cm}(6$ in.) of cobbles and $1.5 \mathrm{~m}$ $(5 \mathrm{ft})$ of sand and gravel.

The tile field was used in this configuration from 1949 to 1959 . The waste stream discharged to the adjacent 216-Z-1 and 216-Z-2 cribs (1949-1952) and the 216-Z-3 Crib (1952-1959) that overflowed to the tile field consisted of neutral to basic ( $\mathrm{pH} 8$ to 10) process waste and analytical and development laboratory waste from the Z Plant via the 241-Z-361 Settling Tank. The total volume discharged from 1949 to 1959 was approximately 1 million L (264,172 gal).

Before the 216-Z-1A Tile Field was reactivated in 1964, a sheet of 0.05-cm (0.02-in.)-thick polyethylene and a 30-cm (1-ft)-thick layer of sand and gravel were added, and the liquid waste discharge piping was routed directly to the central distributor pipe in the tile field. Between 1964 and 1969, a 5-cm (2-in.)-diameter stainless steel pipe was progressively inserted inside the central distributor pipe to divide the tile field into three operational sections (216-Z-1AA, -1AB, and -1AC).

The Plutonium Reclamation Facility (PRF) replaced RECUPLEX in 1964 and operated until 1979. The PRF had essentially the same mission as RECUPLEX and used similar but superior solventextraction-column technology. An 80:20 ratio (by volume) of carbon tetrachloride to TBP was used as the extractant. An americium recovery system was installed in the 242-Z Waste Treatment Facility in 1964. The process used a 70:30 volumetric mixture of carbon tetrachloride and DBBP. Between 1964 and 1970, americium was recovered by batch operation.

From 1964 to 1969, the 216-Z-1A Tile Field received approximately 5.2 million L (1.37 Mgal) of liquid waste from Buildings 234-5Z (PFP), 236-Z (PRF), and 242-Z (Waste Treatment Facility), and miscellaneous laboratory waste along with continued receipt of waste from the 216-Z-1 and 216-Z-2 cribs. Material discharged to the tile field from PFP, PRF and WTF reportedly included $57 \mathrm{~kg}(126 \mathrm{lb})$ of plutonium [9,100 Ci ${ }^{239 / 240} \mathrm{Pu}$ (assuming $6 \%$ by wt. ${ }^{240} \mathrm{Pu}$, DOE/DP 1996)], 3,430 Ci of ${ }^{241} \mathrm{Am}, 268,000 \mathrm{~kg}$ $(591,000 \mathrm{lb})$ of carbon tetrachloride, $30,000 \mathrm{~kg}(66,000 \mathrm{lb})$ of TBP, 20,300 kg (44,800 lb) of DBBP, and $3,000 \mathrm{~kg}(6,615 \mathrm{lb})$ of nitrate (DOE/RL 1992, DOE/RL 1997). The carbon tetrachloride was discharged to the 216-Z-1A Tile Field in combination with other organics, and as a small entrained fraction of process aqueous wastes, and as DNAPL.

\section{A.1.3 241-Z-361 Settling Tank Structure and Waste Disposal Practices}

The 241-Z-361 Settling Tank is located approximately $35 \mathrm{~m}$ (115 ft) north of the 216-Z-1A Tile Field

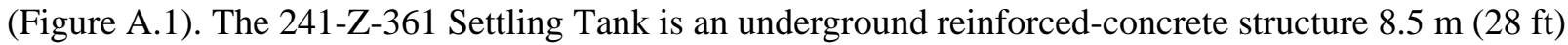
long and $4.5 \mathrm{~m}(15 \mathrm{ft})$ wide, with a $1 \mathrm{~cm}(3 / 8$-in.)-thick steel liner. The tank has inside dimensions of 7.9 by $4.0 \mathrm{~m}$ ( 26 by $13 \mathrm{ft}$ ) with $0.3 \mathrm{~m}$ (1-ft)-thick walls. The bottom slopes, resulting in an internal height variation between 5.2 and $5.5 \mathrm{~m}(17$ and $18 \mathrm{ft})$. The top is $0.6 \mathrm{~m}(2 \mathrm{ft})$ below grade. Two $15 \mathrm{~cm}(6-\mathrm{in}$.)- 
diameter stainless steel inlet pipes from the 241-Z Treatment and Storage Tanks enter the settling tank from the north. A single $20 \mathrm{~cm}$ (8-in.)-diameter stainless steel pipe exits the tank from the south. Several risers are visible above grade.

The tank served as the primary solids settling tank for liquid waste from the 234-5Z, 236-Z, and 242-Z Buildings from 1949 to 1973 . Effluent in the tank was discharged to the 216-Z-1A Tile Field, 216-Z-1 and 216-Z-2 Cribs, and the 216-Z-3 Crib. When the tank was in use, the contents were neutralized by adding fly ash, and later sodium hydroxide, to raise the $\mathrm{pH}$ to the 8 to 10 range. Liquid samples collected in March 1975, however, had a pH as low as 4. Before this characterization, it was assumed that the $\mathrm{pH}$ was greater than 2, which renders the plutonium mostly insoluble (HNF 2001). After 25 years of service, approximately $239 \mathrm{~cm}$ (94 in.) (height) or $62.7 \mathrm{~m}^{3}\left(82.05 \mathrm{yd}^{3}\right)$ of solids remain in the tank. Sludge samples collected from various depths in the tank from 1975 to 1985 indicate that plutonium concentrations range from 0.09 to $1.00 \mathrm{~g} / \mathrm{L}$ of sludge. Based on these measurements, the inventory in the tank was estimated to be between 26 and $75 \mathrm{~kg}(57.3$ and $165.4 \mathrm{lb})$ of plutonium.

Additional sampling was conducted from 1999 to 2001 (HNF 2001). Phase I activities included opening of the 241-Z-361 Settling Tank in 1999. A high-efficiency particulate air (HEPA) filter was installed on a passive vent, which then was monitored for combustible vapors, and a tank-headspace vapor sample was collected and analyzed for VOCs. Volatile and semivolatile organics present in the tank included Freon 2, chloroform, tetrachloroethylene, isobutane, methylcyclopentane, trichloroethylene, and carbon tetrachloride. The Phase I investigation also included an inspection of the inside of the tank using a video camera.

Phase II activities included collection of two full-depth sludge core samples from the tank for detailed chemical analysis, and collection of tank-headspace vapor samples during sludge sampling to evaluate the potential for release of volatile compounds by disturbance of the sludge. Downhole nondestructive assay techniques were used in the existing aluminum dry wells in the 241-Z-361 Settling Tank to provide additional information on the distribution of radioisotopes in the sludge.

Helical piers were installed in 1999 to support an above-ground structure for sampling the tank. These piers extend beneath the depth of the tank bottom, and some are within a few feet of the tank, allowing monitoring of potential radiological contamination upon their removal. Characterization of the tank and sludge indicated about $25 \mathrm{~kg}(55 \mathrm{lb})$ of ${ }^{239} \mathrm{Pu}$ and about $4 \mathrm{~kg}(8.8 \mathrm{lb})$ of other fissile isotopes (primarily ${ }^{240} \mathrm{Pu}$ ) remain in the tank. The $\mathrm{pH}$ of the sludge suggests that the plutonium is insoluble, thus limiting mobility in the event of a leak. Very low concentrations of potentially hazardous materials such as ammonia, nitrates, and organic compounds are in the sludge. Headspace sampling indicates that flammable-gas concentrations are far below the lower flammability limit. In-tank video records suggest that imminent structural failure of the tank is not a concern.

\section{A.2 200-PW-3 Operable Unit Fuel Reprocessing Waste Disposal}

\section{A.2.1 216-A-8 Crib Structure and Waste Disposal Practices}

The 216-A-8 Crib is located approximately $177 \mathrm{~m} \mathrm{(580} \mathrm{ft)} \mathrm{east} \mathrm{of} \mathrm{the} \mathrm{A} \mathrm{Tank} \mathrm{Farm.} \mathrm{The} \mathrm{bottom}$ dimensions of the crib are 259 by $6 \mathrm{~m}$ ( 850 by $20 \mathrm{ft})$. The long axis of the crib trends to the eastnortheast. A $61-\mathrm{cm}$ (24-in.)-diameter, Schedule 20, perforated distribution line extends the length of the crib and rests on a 2-m (6.5-ft)-thick layer of rock capped by a 30-cm (12-in.)-thick layer of gravel. The 
gravel fill is mounded over the distribution line. Two layers of Sisalkraft paper $^{1}$ cover the gravel and prevent overlying native sand backfill from filling the void space. The crib floor was excavated to a uniform elevation of $195 \mathrm{~m}(639.5 \mathrm{ft})$ above mean sea level. The depth of the excavation varied from 4.9 to $5.8 \mathrm{~m}$ ( 16 to $19 \mathrm{ft}$ ) below the 1955 ground surface. The site was surface-stabilized in September

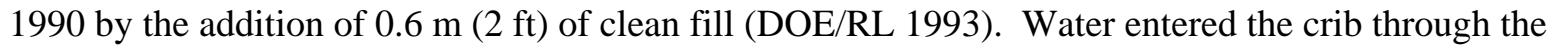
216-A-508 Diversion Box, located due west of the crib. The crib was permanently isolated in April 1995 by filling the 216-A-508 Control Structure with concrete.

The 216-A-8 Crib received vapor condensate from the operation of several ventilation systems associated with the A, AX, AY, and AZ Tank Farms. The A Tank Farms complex first received selfboiling waste from PUREX in early 1956. The self-boiling waste generated a vapor phase that contained radioactive, organic, and inorganic contaminants. Between 1955 and 1958, the vapor phase was mixed directly with cooling water in two contact condensers, resulting in a large volume of liquid waste. During this time, the crib received more than 99 percent of its reported uranium load, 98 percent of its plutonium load, and 83 percent of its beta fission-product load. Approximately 87 percent of the liquid waste, by volume, that the crib received during its 30-year-long operational life came from the contact condenser system during these 30 months (DOE/RL 1993).

In 1960, a surface condenser system was installed in the 241-A-401 Tank Farm Condenser Pit to replace the contact condenser system. This system used cooling water in pipe coils to indirectly contact (i.e., chill) the vapor phase. This condensation system reduced the volume of liquid waste sent to the crib but increased the concentration of most contaminants in the waste. The 241-A-702 Tank Farm Fan House replaced the 241-A-401 Tank Farm Condenser Pit in 1969 and provided de-entrainment filters to control noncondensable vapors exiting the surface condensers. Between 1966 and 1976, the 216-A-8 Crib received more than 149 million L (39.4 Mgal) of liquid waste from the surface condenser system. During this time, the AY and AZ Tank Farms were added to the then-active A and AX Tank Farms. Process changes at PUREX, or in tank farm operations, reduced the concentration of uranium and plutonium transported in vapors to the surface condenser system. The 216-A-8 Crib also received $600 \mathrm{~L}$ (158.4 gal) of surface condenser liquid waste in 1978.

In the early 1980s, surface condenser systems were installed on individual tanks in the AY and AZ Tank Farms. In these systems, the condensed vapor was routed back to the tank. Because the cooling water in the pipe coils could become contaminated by a coil failure or pinhole leak, the waste stream was discharged to cribs. The cooling water routinely would have no, or minimal amounts, of contamination. The 216-A-8 Crib received cooling water from the individual surface condensers in 1983 and from 1984 to 1985 .

Over its operational life, the 216-A-8 Crib received an estimated 1.15 billion L (303.8 Mgal) of process effluent, which is estimated to be greater than 30 times the pore volume beneath the site (DOE/RL 1993; DOE/RL 1997). The hazardous chemical inventory for the 216-A-8 Crib was previously estimated as $320,000 \mathrm{~kg}(705,479 \mathrm{lb})$ of ammonium carbonate, $130,000 \mathrm{~kg}(286,600 \mathrm{lb})$ of TBP, and $50,000 \mathrm{~kg}(110,231 \mathrm{lb})$ of hexone (WHC-EP-0287, Waste Stream Characterization Report). Earlier estimates of the inventory also included $46,000 \mathrm{~kg}(101,412 \mathrm{lb})$ of NPH (refined kerosene) (DOE/RL 1997). However, when the potential dilution factor from the contact condenser system and the potential concentration factor from the improved surface condenser system are taken into account, the calculated

\footnotetext{
${ }^{1}$ Sisalkraft (paper) is a trademark of Fortifiber Corporation, Los Angeles, California.
} 
quantities of TBP and NPH are only approximately $24,030 \mathrm{~kg}(52,977 \mathrm{lb})$ and 8,400 $\mathrm{kg}(18,519 \mathrm{lb})$, respectively. Based on additional evaluations, the inventory of hexone at the $216-\mathrm{A}-8 \mathrm{Crib}$ is believed to be negligible (DOE/RL 2004, Section 2.3.2.4).

The Work Plan (DOE/RL 2004, Section 2.3.2.4) lists the organic inventory for the 216-A-8 Crib, based on the Groundwater/Vadose Zone Integration Project Hanford Soil Inventory Model (SIM, Rev. 0, BHI 2001). The organic inventory (mean values), based on the Hanford Soil Inventory Model, Rev. 1 (SIM, Rev. 1, RPP 2005), includes 128,582 kg (283,470 lb) of TBP; 55,107 kg (121,488 lb) of NPH; $1,364 \mathrm{~kg}(3,007 \mathrm{lb})$ of butanol; and $0.16 \mathrm{~kg}(0.35 \mathrm{lb})$ of ammonia, which is significantly larger than the SIM, Rev. 0, values (BHI 2001). The reason for the difference in the organic inventory between the two models is the changes in the SIM inventory conceptual model for the waste site. The 216-A-8 Crib was considered at its capacity in 1958, but it was intermittently reactivated over a period of years until 1985 . During the review and revision of waste-site definitions between the publication of SIM, Rev. 0 (BHI 2001), and SIM, Rev. 1 (RPP 2005), it was discovered that uncertainty existed concerning whether wastes had been discharged to the 216-A-8 Crib or the 216-A-24 Crib during the times that the 216-A-8 Crib was either inactive or intermittently active (1971-1978). After the 216-A-8 Crib was taken out of service, waste was diverted to the 216-A-24 Crib. The 216-A-24 Crib received PUREX organic waste. These uncertainties were the result of operational issues at the 216-A-508 Diversion Box during the period and, because of the ambiguity surrounding these occurrences, the SIM, Rev. 1, assumed that a significant volume of PUREX organic waste was diverted to, and discharged at, the 216-A-8 Crib.

The Work Plan (DOE/RL 2004, Section 2.3.2.4) listed the radionuclide inventory for the 216-A-8 Crib, based on BHI 2001. The radionuclide inventory (mean values), based on RPP 2005, decayed through January 1, 2001, includes 8.6 Ci of Sr-90; 2,410.3 Ci of Cs-137; 24,560.8 Ci of H-3 (tritium); $390.8 \mathrm{~kg}(861.57 \mathrm{lb})$ of total uranium; and $3.9 \mathrm{Ci}$ of ${ }^{241} \mathrm{Pu}$ (RPP 2005). The radionuclide inventory also increased as a result of the changes in the SIM inventory conceptual model for the waste site.

\section{A.3 200-PW-6 Operable Unit Fuel Reprocessing Waste Disposal}

\section{A.3.1 216-Z-8 French Drain Structure and Waste Disposal Practices}

The 216-Z-8 French Drain is located east of the 234-5Z Building, and approximately $94 \mathrm{~m} \mathrm{(308 \textrm {ft } )}$ northwest of the 216-Z-9 Trench in the 200 West Area. The French drain bottom dimensions form a 1.5

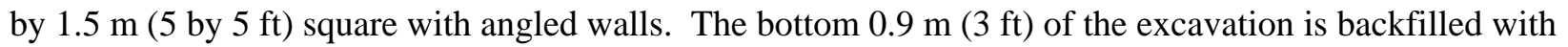
clean, graded gravel. A seal of building paper was laid over the gravel with a $0.9 \mathrm{~m}(3-\mathrm{ft})$-diameter hole

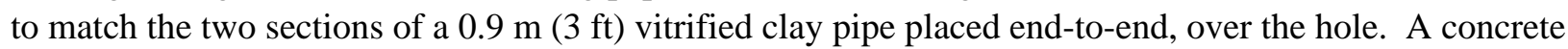
collar was poured around the bottom of the clay pipe, on the top of the building paper. The clay pipe also was filled with gravel and capped with building paper and a wire-mesh-reinforced concrete slab to seal the top of the structure. The overflow pipe from the 241-Z-8 Settling Tank entered through the center of the French drain concrete cap. Woven wire mesh was placed at the opening of the pipe into the French drain to ensure a void space at the waste inlet. The entire structure was backfilled, resulting in the top of

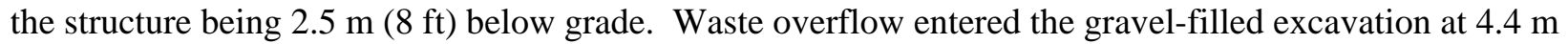
(14 ft) below grade from the 241-Z-8 Settling Tank. The total volume filled with gravel in the French drain was more than $4 \mathrm{~m}^{3}\left(141 \mathrm{ft}^{3}\right)$. The French drain was designed assuming a net porosity of 30 percent, such that more than 1,000 L ( 265 gal) of solution could be accommodated. This was sufficient capacity to permit the waste solution to percolate into the sediments beneath the French drain between batch discharges of waste and rinse water from the 241-Z-8 Settling Tank (RHO 1984). 
The 216-Z-8 French Drain received low-level plutonium-contaminated waste from the 234-5Z Building from 1955 to 1962 . No organic waste was discharged to the 216-Z-8 French Drain. The waste stream was dilute and nearly neutral, with no fission or activation product content, and was relatively low in both disposal rate and total disposal volume. It is estimated that 9,590 L (2,530 gal) of liquid waste containing an estimated $48.2 \mathrm{~g}(1.7 \mathrm{oz})$ of plutonium overflowed from the $241-\mathrm{Z}-8$ Settling Tank to the 216-Z-8 French Drain by the time the French drain was retired in 1962 (RHO 1984).

\section{A.3.2 216-Z-10 Injection/Reverse Well Structure and Waste Disposal Practices}

The 216-Z-10 Injection/Reverse Well is located approximately $30.5 \mathrm{~m}(100 \mathrm{ft})$ east of the $231-\mathrm{Z}$ Building in the 200 West Area. The 216-Z-10 Injection/Reverse Well also has been known as the 231-W Reverse Well, 231-W-151 Dry Well or Reverse Well, 231-Z Well, 299-W15-51, 231-W-150, and 216-Z-2.

The 216-Z-10 Injection/Reverse Well was drilled in September 1944. The well was $0.15 \mathrm{~m}$ (6 in.) in diameter and constructed of Schedule 40 steel pipe. The drilling log reported depth to bottom at $45.7 \mathrm{~m}$ $(150 \mathrm{ft}) \mathrm{bgs}$ and a capped flange extending approximately $0.31 \mathrm{~m}(1 \mathrm{ft})$ above grade. Three inlet pipes

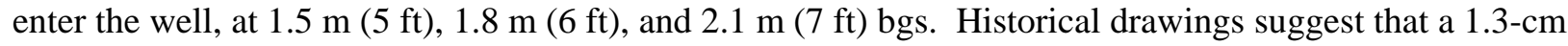
(0.5-in.) copper tube extends from ground surface to $5.1 \mathrm{~m}(2 \mathrm{ft}) \mathrm{bgs}$, where it enters the well, and may extend to the well bottom. The well was perforated from 36 to $45.7 \mathrm{~m}$ (118 to $150 \mathrm{ft}$ ) bgs, with a cement plug in the bottom. On November 24, 1944, the well was tested with 7,571 L (2,000 gal) of water pumped into the well at a rate of $379 \mathrm{~L}$ (100 gal) a minute. The results of this test showed no static water 5 minutes after pumping had stopped (HW 1948). During drilling of well 299-W15-42, it was estimated that the depth to the highest recorded water table in the area of the 216-Z-10 Injection/Reverse Well was $58.22 \mathrm{~m}(191 \mathrm{ft}) \mathrm{bgs}$. This suggests that the water table did not rise to the perforated intervals of the well in later years.

The 216-Z-10 Injection/Reverse Well received process and laboratory waste from the 231-Z Building via the 231-Z-151 Sump between February and June 1945. It is estimated that 988,000 L (260,000 gal) of liquid containing up to $50 \mathrm{~g}(1.7 \mathrm{oz})$ of plutonium was discharged to the well at approximately $76 \mathrm{~L} / \mathrm{min}$ (20 gal/min). No other radionuclides were reported released to the well (HW 1948).

\section{A.4 Review of Geochemical Characterization Data for the 200-PW-1/3/6 Operable Units}

Characterization activities for the Plutonium/Organic-Rich Group OU were prioritized based upon a representative waste site approach. In this approach, waste sites were selected that received waste-stream inventories and effluent volumes that resulted in or could result in subsurface contaminant levels that represented average or worst-case conditions for the waste sites in the OU. The six sites selected based upon this approach were 216-Z-1A Tile Field, 216-Z-9 Trench, 241-Z-361 Settling Tank, 216-Z-8 French Drain, 216-Z-10 Injection/Reverse Well, and the 216-A-8 Crib. The 216-Z-1A Tile Field was selected as the "typical" representative source term waste site in the 200-PW-1 OU because of its plutonium and carbon tetrachloride inventory and the availability of characterization data. The 216-Z-9 Trench was selected as the "worst case" representative source term waste site in the 200-PW-1 OU because it has the highest plutonium inventory and a high volume of carbon tetrachloride-containing effluent released to the subsurface compared to the infiltration capacity of the receiving site. The 241-Z-361 Settling Tank was selected as a representative waste site in the 200-PW-1 OU because it has a high plutonium inventory that 
has not been released to the environment and the availability of characterization data. The 216-Z-8 French Drain and the 216-Z-10 Injection/Reverse Well were selected in the 200-PW-6 OU based on available characterization data and because they were not analogous to any of the other waste sites selected. The 216-A-8 Crib was selected as the "worst case" representative waste site in the 200-PW-3 OU because it has a relatively high fission product inventory compared to other waste sites in the Plutonium/OrganicRich Group OU and a significant inventory of organic solvents including compounds other than carbon tetrachloride.

\section{A.5 Plutonium and Americium Contamination from 216-Z-9 Trench}

\section{A.5.1 Historical Data}

Samples were collected through the roof of the trench to a maximum depth of $3 \mathrm{~m}(9 \mathrm{ft})$ below the trench floor during 1959, 1961, and 1963 and analyzed for the presence of plutonium. Concern over the potential for the accumulation of a critical mass of plutonium on the floor of the trench prompted an additional sampling event through the trench roof during 1973. Both plutonium and americium were detected at relatively high concentrations across the $3 \mathrm{~m}$ profile. Samples from the bottom of the trench to $15 \mathrm{~cm}$ (6 in.) below the floor yielded ${ }^{239} \mathrm{Pu}$ concentrations of up to $1.2 \times 10^{12} \mathrm{pCi} / \mathrm{L}$ (sediment) and americium-241 concentrations of up to $1.4 \times 10^{11} \mathrm{pCi} / \mathrm{L}$ (sediment) were found within $15 \mathrm{~cm}(6 \mathrm{in}$.) of the trench bottom. At a depth of $3 \mathrm{~m}(9 \mathrm{ft}),{ }^{239} \mathrm{Pu}$ and ${ }^{241} \mathrm{Am}$ concentrations were $2.0 \times 10^{9} \mathrm{pCi} / \mathrm{L}$ (sediment) and $1.4 \times 10^{8} \mathrm{pCi} / \mathrm{L}$ (sediment), respectively. Soil $\mathrm{pH}$ was 4.1 at a depth of $2.4 \mathrm{~m}(8 \mathrm{ft})$ and generally

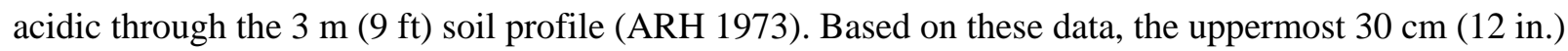
of the trench floor was excavated in 1976 (RHO 1978). See DOE/RL (2007, Section 2.1.3) for a discussion of mining results.

Sediment core samples collected from within the 216-Z-9 Trench were examined by autoradiography and electron microprobe analysis (Price and Ames 1975). The results of these analyses indicated the presence of both particulate and dissolved plutonium. The particulate plutonium had a composition consisting of greater than $70 \%$ (wt \%) $\mathrm{PuO}_{2}$. This material was shown to be filtered out within the first meter underlying the trench profile, and accounting for the high concentrations of $\mathrm{Pu}$ in this are of the sediment profile. Dissolved $\mathrm{Pu}$ (disposed originally as dissolved $\mathrm{Pu}$ IV and less than 0.5 wt $\% \mathrm{PuO}_{2}$ ) penetrated deeper within the sediment profile and was deposited in association with acid induced silicate hydrolysis of the sediment minerals.

Between 1954 and 1967, nine wells were drilled around the 216-Z-9 Trench. Scintillation probe profiles were completed on each of the borings at least once between 1963 and 1970, and at least once more between 1973 and 1976. Radiological contamination was detected in two borings (wells 299-W15-8 and 299-W15-86) at a depth from 15.2 to $38.1 \mathrm{~m}$ (49.5 to $125 \mathrm{ft}$ ) bgs (see ARH 1977 for profiles).

Geophysical logging of well 299-W15-8 revealed ${ }^{239} \mathrm{Pu}$ from 15.1 to $32.3 \mathrm{~m}$ (50 to $106 \mathrm{ft}$ ) bgs.

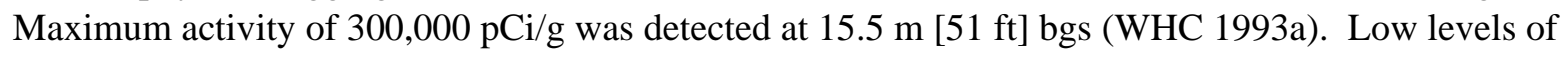
$\mathrm{Pu}$ and Am were detected in groundwater from well 299-W15-8 on May 7, 1990, and November 13, 1991, before the groundwater table declined below the elevation of the bottom of the well and the well went dry. 


\section{A.5.2 Recent Data: Wells 299-W15-46 (Borehole C3426) and 299-W15-48 (Borehole C3427)}

In 2004-2006, well 299-W15-46 (Borehole C3426) and well 299-W15-48 (Borehole C3427) were drilled to better characterize the extent of contamination originating from 216-Z-9 Trench. Geophysical logging using the Spectral Gamma Logging System (SGLS) was performed during these drilling activities. The geophysical log data reports are included in Appendix E of WMP 2005 and Appendix D of WMP 2007. Key findings relevant to this study are summarized below.

\section{A.5.3 Well 299-W15-46}

${ }^{239} \mathrm{Pu}$ and ${ }^{241} \mathrm{Am}$ were detected in borehole well 299-W15-46 but not below $36.6 \mathrm{~m}(120 \mathrm{ft})$. Plutonium-239 was detected between 14.3 and $15.5 \mathrm{~m}$ (47 and $51 \mathrm{ft}$ ), with a maximum concentration of approximately $284,000 \mathrm{pCi} / \mathrm{g}$ at $14.6 \mathrm{~m}$ (48 ft). Plutonium-239 was detected almost continuously between 16.8 and $26.2 \mathrm{~m}$ (55 and $86 \mathrm{ft}$ ) at concentrations ranging from approximately 27,000 to

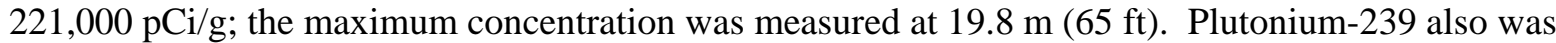
detected at 33.5 and $35.4 \mathrm{~m}$ (110 and $116 \mathrm{ft}$ ) at concentrations of 41,000 and 58,000 pCi/g, respectively.

Americium-241 was detected from 14 to $18.6 \mathrm{~m}$ (46 to $61 \mathrm{ft}$ ), at concentrations ranging from 56,000 to $145,000 \mathrm{pCi} / \mathrm{g}$. It also was detected almost continuously from 19.2 to $36 \mathrm{~m} \mathrm{(63} \mathrm{to} 118 \mathrm{ft})$ at concentrations ranging from just above the minimum detectable level to approximately 20,000 to $400,000 \mathrm{pCi} / \mathrm{g}$; the maximum concentration was measured at $35.4 \mathrm{~m}(116 \mathrm{ft})$.

The passive neutron detector indicated elevated count rates between 14 and $36 \mathrm{~m}$ (46 and $118 \mathrm{ft}$ ). The highest count rates (4 to 5 counts per second) were detected at approximately 14.6, 33.5, and $35.4 \mathrm{~m}$ $(48,110$, and $116 \mathrm{ft})$. At these depths, ${ }^{239} \mathrm{Pu}$ and ${ }^{241} \mathrm{Am}$ also were detected.

\section{A.5.4 Well 299-W15-48}

${ }^{239} \mathrm{Pu}$ and americium-241 were detected in well $299-\mathrm{W} 15-48 ;{ }^{240} \mathrm{Pu}$ also was inferred to exist. Plutonium-239 was generally detected between 15.5 and $37.2 \mathrm{~m} \mathrm{(51} \mathrm{and} 122 \mathrm{ft}$ ) downhole (13.2 to $31.5 \mathrm{~m}$ or 43.3 to $103.5 \mathrm{ft}$ vertical). The dominant interval was between 18.9 and $26.5 \mathrm{~m} \mathrm{(62} \mathrm{and} 87 \mathrm{ft}$ ) downhole (16 to $22.5 \mathrm{~m}$ or 52.6 to $73.8 \mathrm{ft}$ vertical) with a maximum concentration of approximately $657,000 \mathrm{pCi} / \mathrm{g}$ at $22 \mathrm{~m}$ (72 ft) downhole (18.6 m or $61.1 \mathrm{ft}$ vertical). The maximum ${ }^{240} \mathrm{Pu}$ activity in this borehole could be estimated near $40,000 \mathrm{pCi} / \mathrm{g}$.

Americium-241 was detected from 15.5 to $37.2 \mathrm{~m}$ (51 to $122 \mathrm{ft}$ ) downhole ( 13.2 to $31.5 \mathrm{~m}$ or 43.3 to $103.5 \mathrm{ft}$ vertical) at concentrations ranging from 40,000 to $245,000 \mathrm{pCi} / \mathrm{g}$; the maximum concentration was measured at $36.9 \mathrm{~m}(121 \mathrm{ft})$ downhole $(31.3 \mathrm{~m}$ or $102.6 \mathrm{ft}$ vertical). Low energy gamma rays attributed to ${ }^{241} \mathrm{Am}$ were detected that normally would be severely attenuated by the 17/32-in.-thick steel and 1/4-in.-thick polyvinyl chloride casings in the borehole during the logging and by the borehole geophysical tool housing itself. The fact that these gamma rays consistently were detected indicated that the source most likely originates inside the steel casing as a result of internal contamination from the

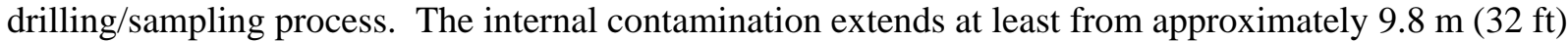

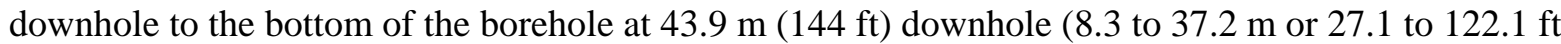
vertical). The effect of this internal contamination is to cause a slight overestimation of radionuclide concentrations. 
The passive neutron detector indicated elevated count rates between 14.3 and $37.5 \mathrm{~m}$ (47 and $123 \mathrm{ft}$ ) downhole (12.2 to $31.8 \mathrm{~m}$ or 39.9 to $104.3 \mathrm{ft}$ vertical). The highest count rates (4 counts per second) were detected where the highest ${ }^{239} \mathrm{Pu}$ concentrations are measured at approximately $19.2 \mathrm{~m}(63 \mathrm{ft})$ downhole ( $16.3 \mathrm{~m}$ or $53.4 \mathrm{ft}$ vertical) and $21.3 \mathrm{~m}(70 \mathrm{ft})$ downhole $(18.1 \mathrm{~m}$ or $59.4 \mathrm{ft}$ vertical); at these depths,

${ }^{241} \mathrm{Am}$ also was detected. This count rate is considerably lower (4 vs. 2,600 counts per second) than observed in other PFP waste disposal sites such as the 216-Z-1A Tile Field and the 216-Z-12 Crib. This suggests that the compounds in the 216-Z-9 Trench are in the form of nitrates or oxides rather than fluorides, as postulated for the other PFP waste disposal sites. Fluorine has a cross section for capturing alpha particles that is 100 times greater than that for the other light elements.

\section{A.5.5 Summary of Soil Analysis Results}

Soil samples collected during the drilling of wells 299-W15-46 and 299-W15-48 at 216-Z-9 Trench were analyzed for a variety of contaminants. Results of the analyses are tabulated in Appendix B of the RI report (DOE/RL 2007). Data for Pu, Am, TBP, pH, and nitrate are discussed below.

\section{A.5.6 Well 299-W15-46}

Maximum concentration results for $\mathrm{Pu}, \mathrm{Am}$, and TBP and the lowest $\mathrm{pH}$ value, along with the depth interval for soil samples collected during the drilling of Well 299-W15-46 are presented in Table A.1. It is notable that the highest ${ }^{239 / 240} \mathrm{Pu}$ result is coincident with both the highest TBP result and the lowest $\mathrm{pH}$ value measured. This suggests that ${ }^{239 / 240} \mathrm{Pu}$ may have migrated through the vadose zone relatively unimpeded along with the organic and/or acidic high salt aqueous waste streams.

Table A.1. Maximum Concentration, and Depth Interval for ${ }^{239 / 240} \mathrm{Pu},{ }^{241} \mathrm{Am}$, TBP; and Lowest $\mathrm{pH}$ Value and Depth Interval, Well 299-W15-46

\begin{tabular}{||c|c|c|c||}
\hline \multirow{2}{*}{ Constituent or Parameter } & \multirow{2}{*}{$\begin{array}{c}\text { Maximum } \\
\text { Concentration }\end{array}$} & \multicolumn{2}{|c|}{ Depth Interval (ft bgs) } \\
\cline { 3 - 4 } & $115,000 \mathrm{pCi} / \mathrm{g}$ & 63.5 & 66 \\
\hline \hline Plutonium-239/240 & $324,000 \mathrm{pCi} / \mathrm{g}$ & 47.5 & 50 \\
\hline Americium-241 & $2,100 \mathrm{mg} / \mathrm{kg}$ & 63.5 & 66 \\
\hline $\mathrm{TBP}$ & 3.9 & 63.5 & 66 \\
\hline $\mathrm{pH}$ & \multicolumn{2}{|l}{} \\
\hline
\end{tabular}

$\mathrm{Pu}, \mathrm{Am}$, and TBP concentration data are plotted as a function of average core depth bgs in Figure A.2. The bottom of a silt layer that occurs at about 65 feet bgs is indicated as well as the bottom of the Cold Creek unit at about $120 \mathrm{ft}$ bgs. High concentrations of $\mathrm{Pu}, \mathrm{Am}$, and TBP occur at one location above the bottom of the silt layer indicating that Pu migrated with co-contaminants during the operational period. It also appears that this upper silt layer has prevented significant vertical migration of TBP, $\mathrm{Pu}$ and Am below this layer (i.e., the concentration of TBP, Pu and Am just below the silt layer are significantly lower than concentrations observed within the silt layer). The same argument would appear to hold for Am in the Cold Creek unit in the absence of Am concentration data below the Cold Creek unit. These results suggest that at this location, the silt layer and Cold Creek units are acting as significant barriers to further vertical migration of $\mathrm{Pu}$ and $\mathrm{Am}$. 


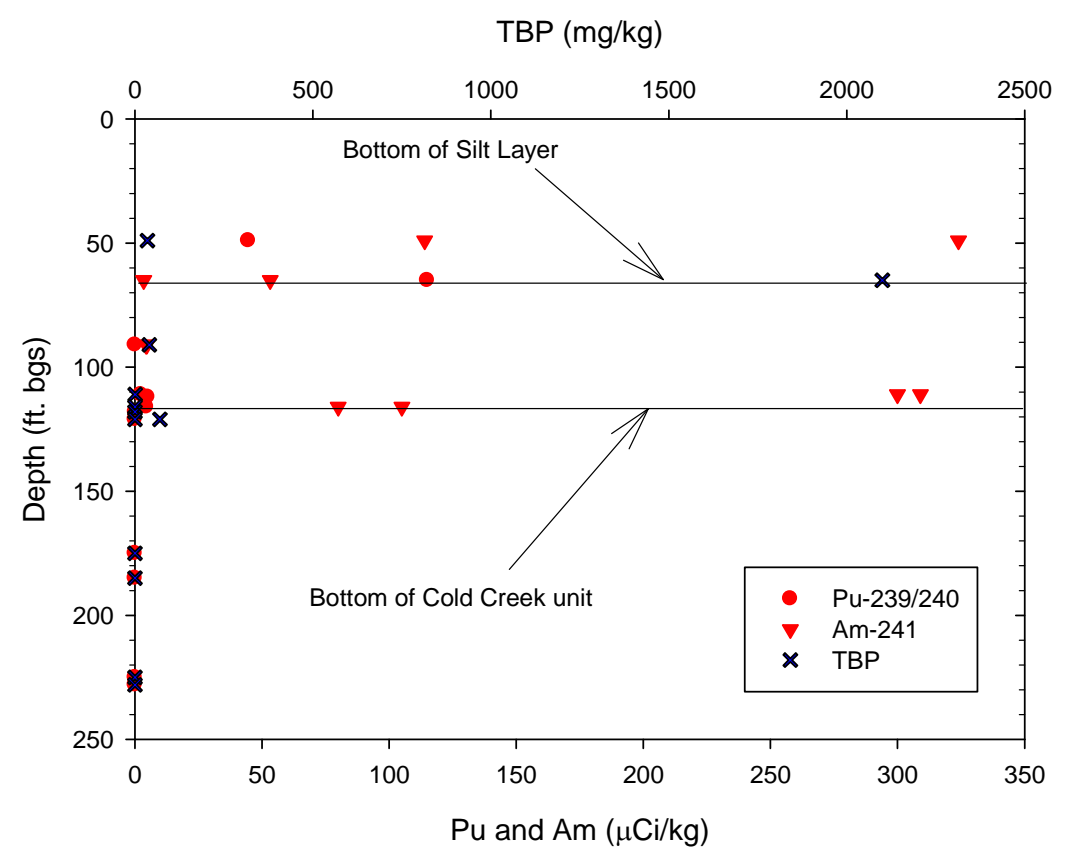

Figure A.2. Pu, Am, and TBP Concentrations as a Function of Depth Measured in Soil Samples from Well 299-W15-46

$\mathrm{Pu}, \mathrm{Am}$, and $\mathrm{pH}$ data as a function of average core depth bgs are shown in Figure A.3. A number of low values of $\mathrm{pH}$ are indicated on this graph. A sample collected from the average core depth of $65 \mathrm{ft}$ bgs has a particularly low $\mathrm{pH}$ value of 3.9. Other low values of 6.0 and 6.6 are located at average core depths of $111 \mathrm{ft}$ bgs, and $49 \mathrm{ft}$ bgs, respectively. These results suggest that significant impacts (e.g., loss of buffering capacity of the sediment) have occurred to sediment (e.g. the Hanford sands and gravels) underlying the 216-Z-9 Trench as a result of acidic high salt aqueous wastes. Impacts to the silt layer and Cold Creek unit has also occurred but apparently not sufficient to prevent attenuation of $\mathrm{Pu}$ and $\mathrm{Am}$ to occur in these layers. High concentrations of Am occur above both the silt layer and the Cold Creek unit and at locations where values of $\mathrm{pH}$ are below neutral.

Nitrate data for Well 299-W15-46 as a function of average core depth bgs is shown in Figure A.4. These data indicate that the acidic high salt wastes disposed to the Z-9 Trench traveled vertically down to the Cold Creek unit, where it encountered the calcium carbonate in the lower "caliche" layer. This layer appears to have been effective at buffering the acidic waste coming into contact with this layer and preventing significant further downward migration of the waste below the Cold Creek unit. It is assumed that lateral spreading of the acidic waste occurred above the silt layer and the Cold Creek unit at this location.

\section{A.5.7 Well 299-W15-48}

Maximum concentration results for $\mathrm{Pu}, \mathrm{Am}$, and TBP, along with the depth interval, for soil samples collected during the drilling of Well 299-W15-48 are presented in Table A.2. No pH values are available for the Well 299-W15-48 soil samples. As was the case for Well 299-W15-46, data for Well 299-W1548 indicate that the highest concentrations of $\mathrm{Pu}$ and TBP occur at the same depth indicating that $\mathrm{Pu}$ migrated with co-contaminants during the operational period. 


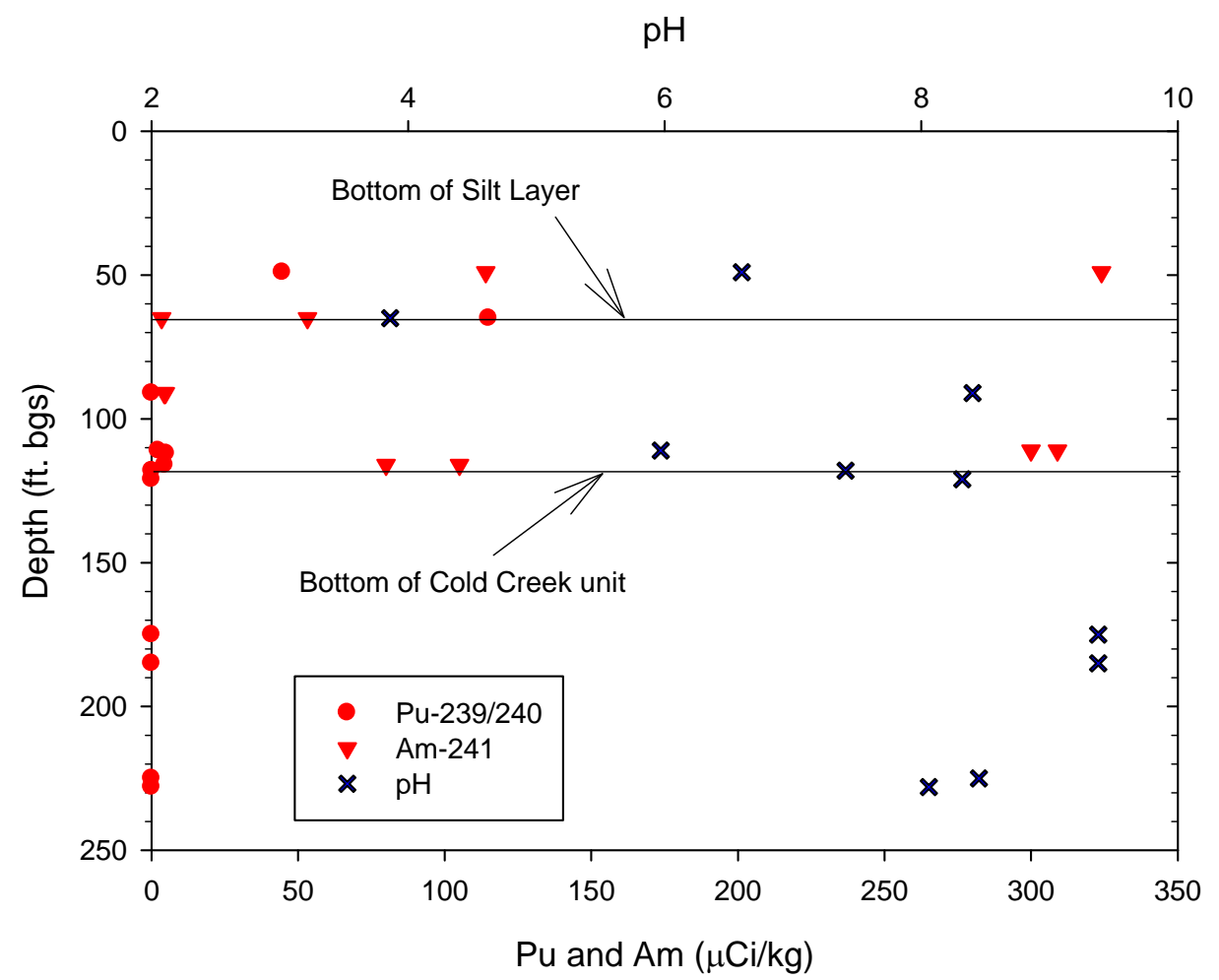

Figure A.3. Pu, Am, and pH as a Function of Depth Measured in Soil Samples from Well 299-W15-46

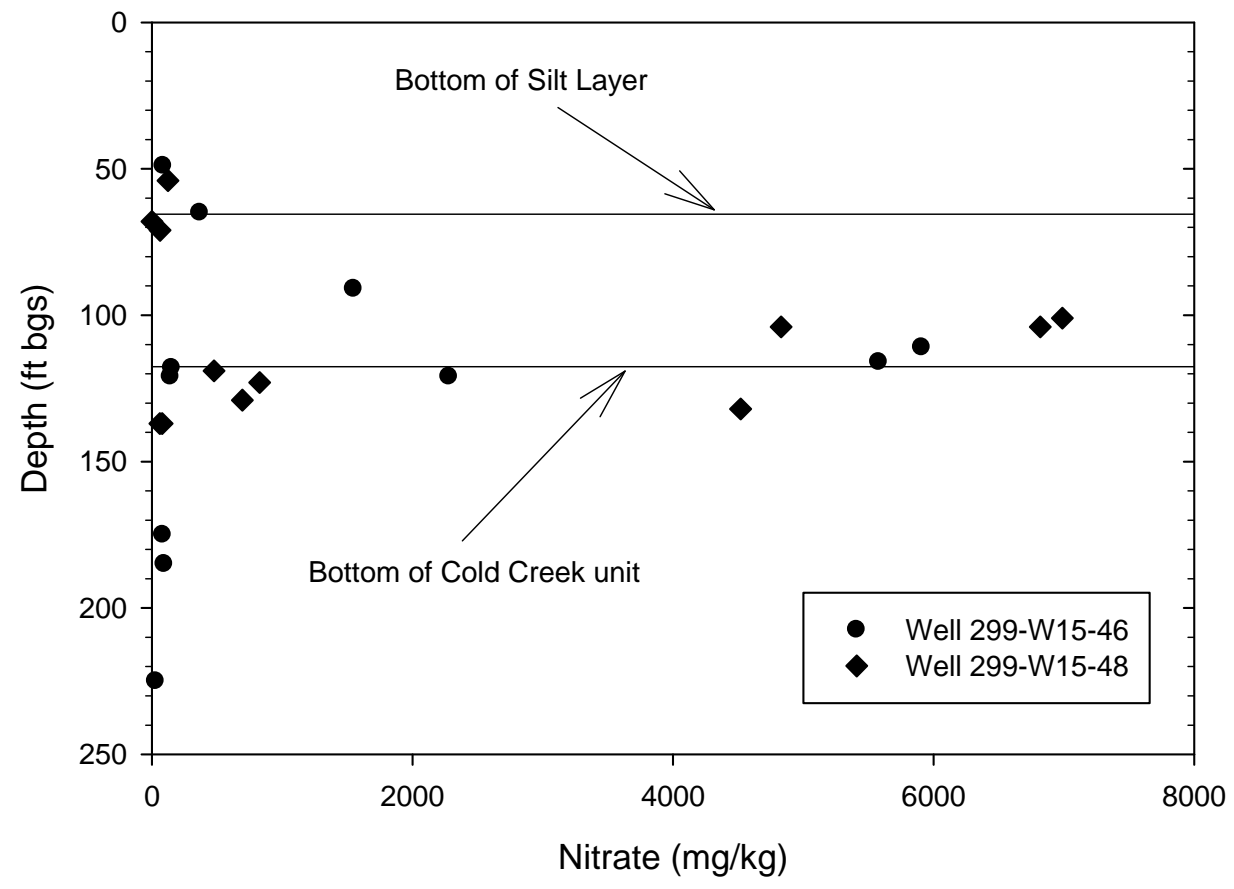

Figure A.4. Nitrate Concentrations as a Function of Depth Measured in Soil Samples from Wells 299-W15-46 and 299-W15-48 
Table A.2. Maximum Concentration, and Depth Interval for ${ }^{239 / 240} \mathrm{Pu},{ }^{241} \mathrm{Am}$, and TBP, Well 299-W15-48.

\begin{tabular}{||c|c|c|c||}
\hline \multirow{2}{*}{$\begin{array}{c}\text { Radionuclide Contaminant } \\
\text { of Potential Concern }\end{array}$} & Maximum Concentration & \multicolumn{2}{|c|}{ Depth Interval (ft bgs) } \\
\cline { 3 - 4 } & $254,000 \mathrm{pCi} / \mathrm{g}$ & 70 & 72 \\
\hline \hline Plutonium-239/240 & $131,000 \mathrm{pCi} / \mathrm{g}$ & 118.5 & 120.5 \\
\hline Americium-241 & $3,000 \mathrm{mg} / \mathrm{kg}$ & 70 & 72 \\
\hline TBP & \multicolumn{2}{|l}{} \\
\hline
\end{tabular}

$\mathrm{Pu}, \mathrm{Am}$, and TBP concentration data for Well 299-W15-48 as a function of average core depth below ground surface are shown in Figure A.5. These data are consistent with that of Well 299-W15-46, indicating that vertical migration of TBP and associated Pu appears to have been (slowed significantly (i.e., highly attenuated) within the silt layer located at about 65 feet bgs. Attenuation of some of the Am occurred in this layer. The acidic high salt component of the aqueous waste stream was able to breach this layer and continue its downward migration to the Cold Creek unit carrying with it Am and a small amount of the $\mathrm{Pu}$ in the waste. Am and a small amount of $\mathrm{Pu}$ showed attenuation within and at the bottom of the Cold Creek unit. Vertical migration of Pu and Am appears to have been stopped below the Cold Creek unit where $\mathrm{Pu}$ and Am concentration are low. This layer appears to have been effective at buffering the acidic waste (see Figure A.4) coming into contact with this layer and preventing significant further downward migration of the waste below the Cold Creek unit. It is assumed that lateral spreading of the acidic waste occurred above the silt layer and the Cold Creek unit at this location.

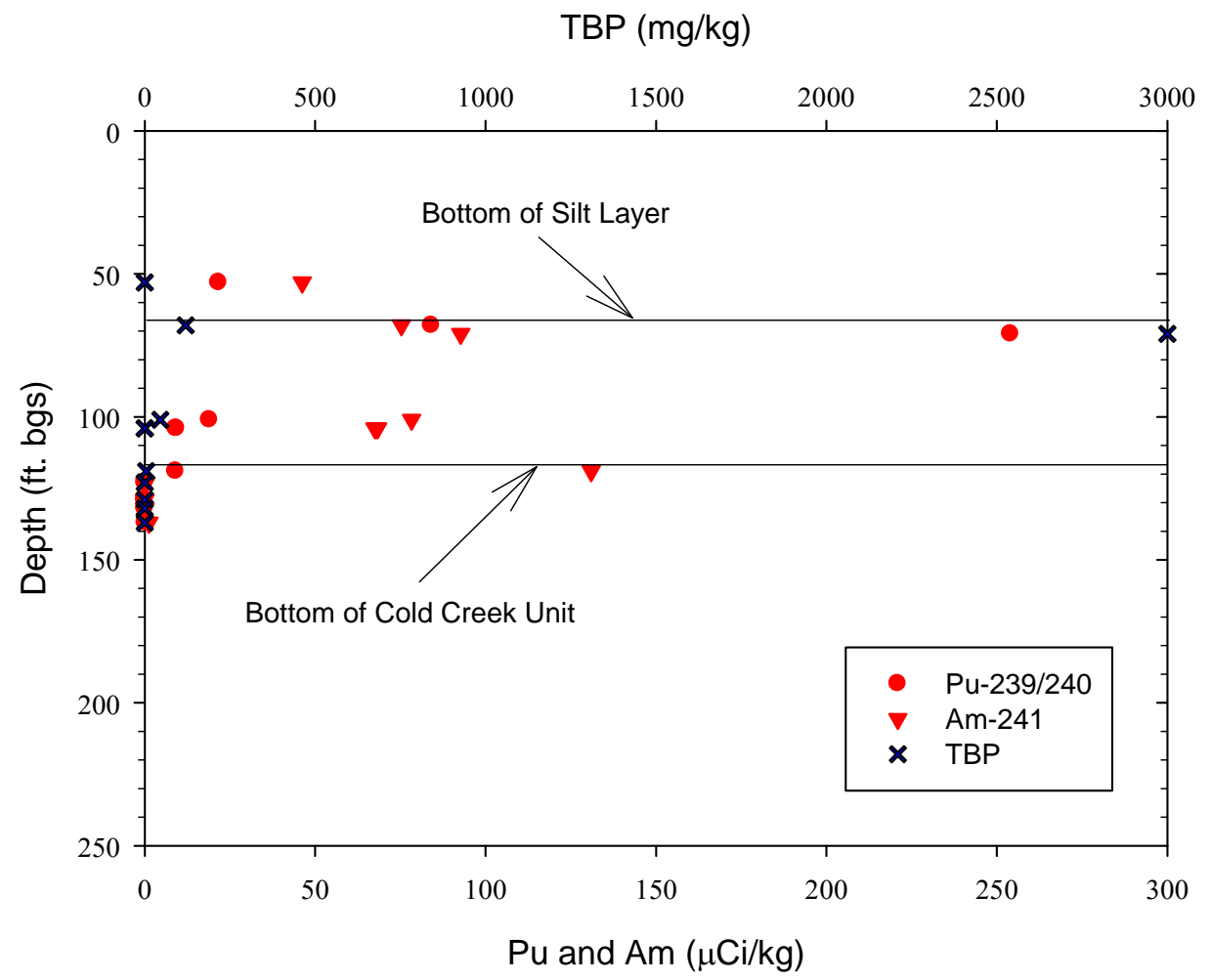

Figure A.5. Pu, Am, and TBP Concentrations as a Function of Depth Measured in Soil Samples from Well 299-W15-48 


\section{A.6 Plutonium and Americium Contamination from the 216-Z-1A Tile Field}

\section{A.6.1 Historical Data}

Before 1973, scintillation (gross gamma) surveys were used as the principal means of detecting contamination from gamma-emitting radionuclides. In 1963, all scintillation probe profiles monitoring the tile field indicated background levels of radiation. Available scintillation profiles are documented in ARH 1977. By 1973, 26 wells had been drilled in and around the 216-Z-1A Tile Field. No chemical data were collected from these 26 wells.

Radioactive contaminants were detected in three boreholes (wells 299-W18-56, 299-W18-57, and 299-W18-58) at the tile field in 1965 (ARH 1977). The maximum vertical extent of contamination $(21.3 \mathrm{~m}[70 \mathrm{ft}])$ was observed in well 299-W18-56. The radiation intensity increased in two of these wells between 1965 and 1968 as a result of continuing disposal. Radiation intensity decreased 3 years after discharges to the tile field were terminated in 1969. Based on the scintillation profiles in ARH 1977, radioactive contaminants were detected relatively high up in the sediment column beneath the tile field, and breakthrough to groundwater had not occurred.

Sixteen boreholes were drilled starting in 1973 and soil samples were collected and subjected to analysis to determine the distribution of plutonium and americium in sediments beneath the tile field

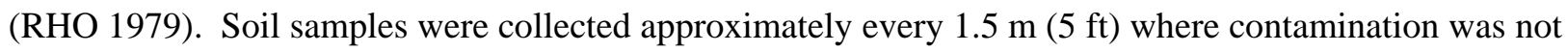

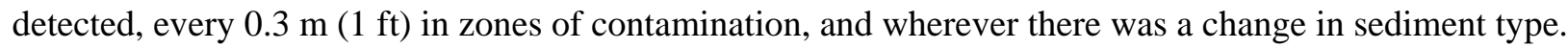
Screening of sediments was performed with portable radiation survey instruments. Selected samples were analyzed by granulometric and actinide analytical techniques. Results of the investigation concluded that:

- The highest concentration of ${ }^{239 / 240} \mathrm{Pu}(40,000,000 \mathrm{pCi} / \mathrm{g})$ and ${ }^{241} \mathrm{Am}(2,500,000 \mathrm{pCi} / \mathrm{g})$ occurred in sediments located immediately beneath the crib, below the distribution pipe.

- The concentration of actinides in sediments generally decreased with depth beneath the waste-distribution system, with the exception of silt-enriched horizons and boundary areas between major sedimentary units.

- The maximum vertical extent of actinide contamination (defined by the $10 \mathrm{pCi} / \mathrm{g}$ isopleth) was located approximately $30 \mathrm{~m}(100 \mathrm{ft})$ below the bottom of the crib and $30 \mathrm{~m}(100 \mathrm{ft})$ above the 1978 water table.

- The estimated lateral extent of contamination was within a $10 \mathrm{~m}$ (33-ft) wide zone encompassing the perimeter of the crib.

\section{A.6.2 Geophysical Logging Summary at the 216-Z-1A Tile Field}

The Radionuclide Logging System has been used to evaluate the extent of radiological contamination in 13 boreholes in and adjacent to the 216-Z-1A Tile Field. Most of the boreholes were logged in 1993 and 1998 (Horton and Randall 1998). ${ }^{239} \mathrm{Pu}$ and ${ }^{241} \mathrm{Am}$ were two of three dominating radionuclides detected during logging of these boreholes. Maximum contaminant levels generally were detected along the central axis of the tile field near the main discharge pipe at wells 299-W18-81, 299-W18-149, 299-W18-159, and 299-W18-170. Results from the survey indicate that higher levels of contamination were detected on the north end of the tile field (head end) associated with the main discharge pipe. 
Contamination generally decreased with depth and distance from the discharge pipe and head end of the tile field. Maximum activities typically were detected at depth within $3.4 \mathrm{~m}(11 \mathrm{ft}) \mathrm{of}$ the discharge pipe.

The maximum vertical extent of radiological contamination ( $8 \mathrm{pCi} / \mathrm{g}$ of $\mathrm{Pa}-233$ ) detected was at $37 \mathrm{~m}$ $(121 \mathrm{ft}) \mathrm{bgs}$ at borehole well 299-W18-174. However, the bulk of the contamination detected was at a depth of less than $21.3 \mathrm{~m}$ (70 ft) bgs. Maximum ${ }^{239} \mathrm{Pu}$ and ${ }^{241} \mathrm{Am}$ activities detected in well 299-W18-159 were $25,000,000 \mathrm{pCi} / \mathrm{g}$ and $2,590,000 \mathrm{pCi} / \mathrm{g}$, respectively.

\section{A.6.3 216-Z-1A Tile Field Contamination - Analytical Data}

The radioactive COPCs ${ }^{241} \mathrm{Am}$ and ${ }^{239 / 240} \mathrm{Pu}$ for the 200-PW-1 OU were detected in the vadose-zone soil beneath the 216-Z-1A Tile Field in wells 299-W18-149, 299-W18-150, 299-W18-159, 299-W18-163, 299-W18-164, 299-W18-165, 299-W18-166, 299-W18-167, 299-W18-168, 299-W18-169, 299-W18-172, 299-W18-173, 299-W18-174, and 299-W18-175. In addition, ${ }^{239 / 240} \mathrm{Pu}$ was detected in wells 299-W18-85, 299-W18-86, 299-W18-87, and 299-W18-88, and ${ }^{241}$ Am was detected in well 299-W18-171. Plutonium-239/240 was detected above background to a maximum depth of $41.8 \mathrm{~m}$ (137.14 ft) in well 299-W18-156. Americium-241 was detected at a maximum depth of $46.8 \mathrm{~m}$ (153.54 ft) in well 299-W18-164. The results for the plutonium and americium analyses are presented in Appendix D of the RI (DOE/RL 2007). The maximum concentration, borehole number and depth interval for ${ }^{239 / 240} \mathrm{Pu}$ and ${ }^{241} \mathrm{Am}$ are shown in Table A.3.

Table A.3. Maximum Concentration, Borehole Number and Depth Interval for ${ }^{239 / 240} \mathrm{Pu}$ and ${ }^{241} \mathrm{Am}$

\begin{tabular}{|c|c|c|c|c|}
\hline \multirow{2}{*}{$\begin{array}{l}\text { Radionuclide Contaminant } \\
\text { of Potential Concern }\end{array}$} & \multirow{2}{*}{$\begin{array}{l}\text { Maximum Concentration } \\
\qquad(\mathrm{pCi} / \mathrm{g})\end{array}$} & \multirow[b]{2}{*}{ Borehole Number } & \multicolumn{2}{|c|}{ Depth Interval (ft bgs) } \\
\hline & & & Top & Bottom \\
\hline Plutonium-239/240 & $38,200,000$ & 299-W18-149 & 11.2 & 11.2 \\
\hline Americium-241 & $2,590,000$ & 299-W18-149 & 11.2 & 11.2 \\
\hline \multicolumn{5}{|c|}{$\begin{array}{l}\text { Data from RHO 1979, Distribution of Plutonium and Americium Beneath the 216-Z-1A Crib: A Status Report; see } \\
\text { Appendix D of DOE/RL (2007). } \\
\text { bgs = below ground surface. }\end{array}$} \\
\hline
\end{tabular}

\section{A.7 Plutonium and Americium Contamination from the 241-Z-361 Settling Tank}

Findings from the Remedial Investigation report (DOE/RL 2007) indicate that no radiological contamination exists in the soils beneath the 241-Z-361 Settling Tank, suggesting that no leaks have occurred from this tank. Based on this finding, no further discussion of the 241-Z-361 Settling Tank is included here.

\section{A.8 Plutonium and Americium Contamination from the 216-A-8 Crib}

Available data for this representative waste site include historical and new geophysical logging results and new soil and soil-vapor sampling results. The data and analysis were integrated to develop and refine a contaminant distribution model for the representative waste site. A summary of important findings related to the 218-A-8 Crib from the Remedial Investigation report (DOE/RL 2007) indicate the following. The highest radiological contamination associated with the crib was detected within $18 \mathrm{~m}$ $(60 \mathrm{ft})$ of the ground surface. The maximum extent of radiological contamination detected near the crib 
by geophysical logging techniques was $76.5 \mathrm{~m}(251 \mathrm{ft})$ bgs. However, the source of the contamination at this depth is not known. The maximum concentration of ${ }^{239 / 240} \mathrm{Pu}$ determined in the vadose zone beneath the 216-A-8 Crib was found in Borehole C4545. The maximum concentration of ${ }^{239 / 240} \mathrm{Pu}$ determined in Borehole C4545 was $55.7 \mathrm{pCi} / \mathrm{g}$ in a depth interval of 19 to $21.5 \mathrm{ft}$ bgs.

\section{A.9 Plutonium and Americium Contamination from the 216-Z-8 French Drain}

Characterization well 299-W15-202 was drilled in 1980, and soil samples were collected to define the plutonium and americium distribution beneath the 216-Z-8 French Drain (RHO 1984). The well was

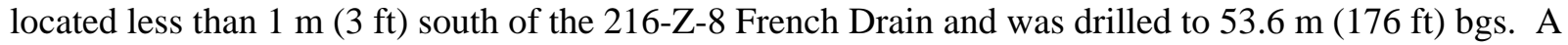
maximum ${ }^{239} \mathrm{Pu}$ value of $4,620 \mathrm{pCi} / \mathrm{g}$ was reported at $7.6 \mathrm{~m}(25 \mathrm{ft}) \mathrm{bgs}$. A maximum value of $457 \mathrm{pCi} / \mathrm{g}$ ${ }^{241} \mathrm{Am}$ was reported at $6.1 \mathrm{~m}(20 \mathrm{ft}) \mathrm{bgs}$, near the bottom of the 216-Z-8 French Drain structure. Results indicate that plutonium and americium were sorbed onto sediments within a few meters beneath the French drain. Based on these results, the nature and extent of contamination are suspected to be confined to a shallow vadose zone directly adjacent to the 216-Z-8 French Drain. It is unlikely that the contaminants disposed to the 216-Z-8 French Drain reached groundwater.

\section{A.10 Plutonium and Americium Contamination from the 216-Z-10 Injection/Reverse Well}

In 1947, three monitoring wells (299-W15-59, 299-W15-60, and 299-W15-61) were drilled $4.6 \mathrm{~m}$ (15 ft) from the 216-Z-10 Injection/Reverse Well for the collection of characterization soil samples (HW 1948). The wells were drilled to $53.3 \mathrm{~m}$ (175 ft) bgs, which was $7.6 \mathrm{~m}$ (25 ft) below the bottom of the reverse well. Samples were collected at a minimum frequency of every $1.5 \mathrm{~m}(5 \mathrm{ft})$, and every $0.3 \mathrm{~m}$ $(1 \mathrm{ft})$ where contamination was suspected to exist. A total 210 soil samples from the three monitoring wells were collected, including field duplicates, and analyzed in the laboratory using an alpha counter (HW 1948). HW (1948) did not state the method reporting limit that was used; therefore, the method reporting limit from HW (1952), of $0.15 \mathrm{pCi} / \mathrm{g}$, was used as a surrogate value. Contamination, specifically plutonium, was not detected in any of the soil samples. In 2005, passive neutron logging to detect alpha contamination was conducted at this site, and the results confirm the HW (1948) findings that

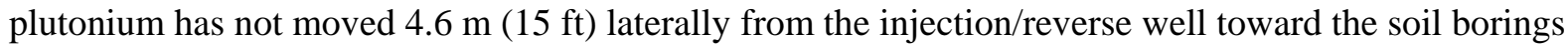
(completed as vadose-zone wells 299-W15-59, 299-W15-60, and 299-W15-61).

\section{A.11 References}

ARH. 1973. Nuclear Reactivity Evaluations of 216-Z-9 Enclosed Trench. ARH-2915, Atlantic Richfield Hanford Company, Richland, Washington.

ARH. 1977. Evaluation of Scintillation Probe Profiles from 200 Area Crib Monitoring Wells. ARH-ST156, Atlantic Richfield Hanford Company, Richland, Washington.

BHI. 2001. Groundwater/Vadose Zone Integration Project Hanford Soil Inventory Model. BHI-01496, Rev. 0, Bechtel Hanford, Inc., Richland, Washington.

DOE/DP. 1996. Plutonium: The First 50 Years. DOE/DP-0137, U.S. Department of Energy, Richland Operations Office, Richland, Washington. 
DOE/RL. 1992. Z Plant Source Aggregate Area Management Study Report. DOE/RL-91-58, Rev. 0, U.S. Department of Energy, Richland Operations Office, Richland, Washington.

DOE/RL. 1993. PUREX Plant Source Aggregate Area Management Study Report. DOE/RL-92-04, Rev. 0. U.S. Department of Energy, Richland Operations Office, Richland, Washington.

DOE/RL. 1997. Waste Site Grouping for 200 Areas Soil Investigations. DOE/RL-96-81, Rev. 0, U.S. Department of Energy, Richland Operations Office, Richland, Washington.

DOE/RL. 2004. Plutonium/Organic Rich Process Condensate/Process Waste Group Operable Unit RI/FS Work Plan, Includes: 200-PW-1, 200-PW-3, and 200-PW-6 Operable Units. DOE/RL-2001-01, Rev. 0, Reissue, U.S. Department of Energy, Richland Operations Office, Richland, Washington.

DOE/RL. 2007. Remedial Investigation Report for the Plutonium/Organic-Rich Process Condensate/Process Waste Group Operable Unit: Includes the 200-PW-1, 200-PW-3, and 200-PW-6 Operable Units. DOE/RL-2006-51, Rev. 0, prepared for the U.S. Department of Energy, Richland, Washington.

HNF. 2001. 241-Z-361 Tank Characterization Report. HNF 8735, Rev. 0A, Fluor Hanford, Inc., Richland, Washington.

Horton DG and RR Randall. 1998. Results of 1998 Spectral Gamma Ray Monitoring of Boreholes at the 216-Z-1A Tile Field, 216-Z-9 Trench, and 216-Z-12 Crib. PNNL-11978, Pacific Northwest National Laboratory, Richland, Washington.

HW. 1948. Underground Waste Disposal at Hanford Works. HW-9671, General Electric Company, Richland, Washington.

Price SM and LL Ames. 1975. "Characterization of Acinide-Bearing Sediments Underlying Liquid Waste Disposal Facilities at Hanford.” ARH-SA-232, Atlantic Richfield Hanford Company, Richland, Washington.

RHO. 1978. Report on Plutonium Mining Activities at 216 Z 9 Enclosed Trench. RHO-ST-21, Rockwell Hanford Operations, Richland, Washington.

RHO. 1979. Distribution of Plutonium and Americium Beneath the 216-Z-1A Crib: A Status Report. RHO-ST-17, Rockwell Hanford, Inc., Richland, Washington.

RHO. 1984. 216-Z-8 French Drain Characterization Study. RHO-RE-EV-46P, Rockwell Hanford Operations, Richland, Washington.

Ridgway KR, MD Veatch and DT Crawley. 1971. 216-Z-9 Crib History and Safety Analysis. ARH2207, Atlantic Richfield Hanford Company, Richland, Washington.

RPP. 2005. Hanford Soil Inventory Model. RPP-26744, Rev. 1, Rev. 0, CH2M HILL Hanford Group, Inc., Richland, Washington. 
WHC. 1993a. Results of Spectral Gamma Ray Logging of Select Boreholes for the 200 Aggregate Area Management Study. WHC-SD-EN-TI-021, Rev. 0, Westinghouse Hanford Company, Richland, Washington.

WMP. 2005. Borehole Summary Report for Well 299-W15-46 (C3426) Drilled at the 216-Z-9 Trench. WMP-26264, Rev. 0, Fluor Hanford, Inc., Richland, Washington.

WMP. 2007. Borehole Summary Report for Well 299-W15-48 (C3427) Drilled at the 216-Z-9 Trench. WMP-30566, Fluor Hanford, Inc., Richland, Washington. 
Appendix B

Geologic Description of the 200-PW-1/3/6 Operable Units 


\section{Appendix B}

\section{Geologic Description of the 200-PW-1/3/6 Operable Units}

The material in this appendix has been taken in large part from DOE/RL (2007). The 200-PW-1, 200-PW-3, and 200-PW-6 OUs are located in the Pasco Basin, one of several structural and topographic basins of the Columbia Plateau. Basalts of the Columbia River Basalt Group and a sequence of suprabasalt sediments underlie the representative waste sites and the dispersed carbon tetrachloride vadose zone plume. From oldest to youngest, the major geologic units of interest are the Elephant Mountain Member of the Saddle Mountains Basalt Formation, Columbia River Basalt Group, the Ringold Formation, the Cold Creek unit (CCU), the Hanford formation, and surficial deposits. Figure B.1 shows a generalized stratigraphic column for the 200 Areas.

\section{B.1 Geology of the 200-PW-1/3/6 Operable Units}

\section{B.1.1 Elephant Mountain Member}

The Elephant Mountain Member of the Saddle Mountains Basalt Formation, Columbia River Basalt Group, is the uppermost basalt unit (i.e., bedrock) in the 200 Areas (DOE/RL 1999, Appendix F). Except for a small area north of the 200 East Area boundary where it has been eroded away, the Elephant Mountain Member is laterally continuous throughout the 200 Areas. The Remedial Investigation (RI) field investigations did not penetrate to the basalt.

\section{B.1.2 Ringold Formation}

The Ringold Formation consists of an interstratified fluvial lacustrine sequence of unconsolidated to semiconsolidated clay, silt, sand, and granule to cobble gravel deposited by the ancestral Columbia River (Williams et al. 2001,. 2002). These sediments, shown in Figure B.1, consist of four major units (from oldest to youngest): the fluvial gravel and sand of Unit 9 (basal coarse); the buried soil horizons, overbank, and lake deposits of Unit 8 (lower mud); the fluvial sand and gravel of Unit 5 (upper coarse); and the lacustrine mud of Unit 4 (upper fines). Units 9 and 5 consist of silty sandy gravel with secondary lenses and interbeds of gravelly sand, sand, and muddy sands to silt and clay. Unit 8 (lower mud) consists mainly of silt and clay. Unit 4 (upper fines) consists of silty overbank deposits and fluvial sand. Units 6 and 7 are not present beneath the 200 West and East Areas; Unit 4 is not present in the 200 East Area, and it is discontinuous in the 200 West Area (Williams et al. 2001, 2002). The two RI boreholes at the 216-Z-9 Trench penetrated into the Ringold Formation Unit 5. The RI borehole at the 216-A-8 Crib penetrated into Ringold Unit 9. Boreholes drilled as part of the carbon tetrachloride dispersed plume investigation also penetrated into the Ringold Formation Unit 9.

\section{B.1.3 Cold Creek unit}

The CCU includes several post-Ringold Formation and pre-Hanford formation units present beneath a portion of the 200 East and West Areas (DOE/RL 2002, Standardized Stratigraphic Nomenclature for Post Ringold Formation Sediments Within the Central Pasco Basin). The CCU includes the sediments 


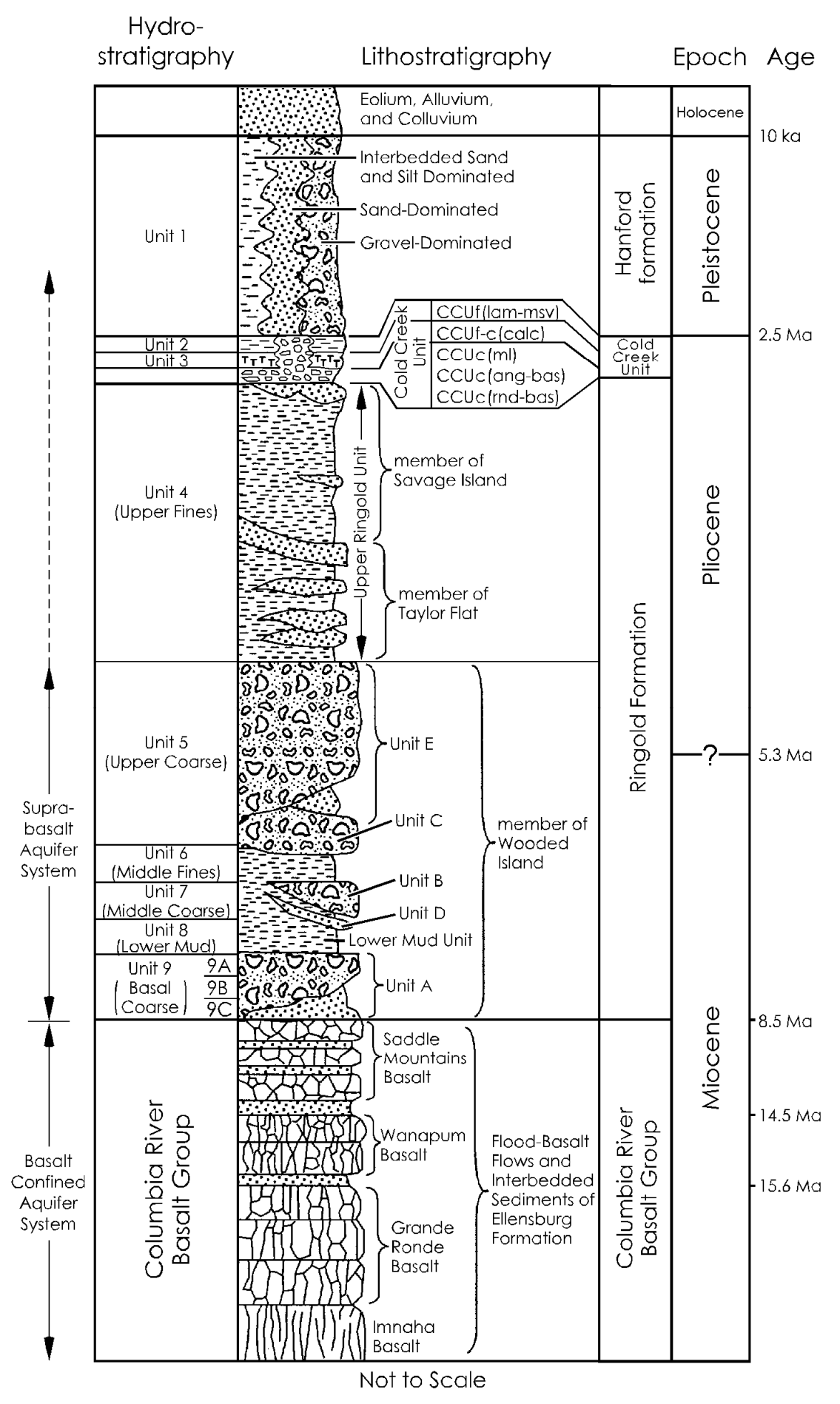

Figure B.1. Generalized Stratigraphic Column for the 200 Areas (modified from Barnett et al. [2006]

formerly identified as the Plio-Pleistocene unit, caliche, early Palouse soil, pre-Missoula gravels, and sidestream alluvial facies in previous site reports. The CCU has been divided into five lithofacies: finegrained, laminated to massive (fluvial overbank and/or eolian deposits, formerly the early Palouse soil); fine- to coarse-grained, calcium carbonate cemented (calcic paleosol, formerly the caliche); coarse- 
grained, multilithic (mainstream alluvium, formerly the pre-Missoula gravels); coarse-grained, angular, basaltic (colluvium); and coarse-grained, rounded, basaltic (sidestream alluvium, formerly sidestream alluvial facies) (DOE/RL 2002). The two RI boreholes at the 216-Z-9 Trench penetrated the CCU. At the 216-Z-9 Trench, the CCU is present from about 33 to $36 \mathrm{~m}$ (108.27 to $118.11 \mathrm{ft})$ depth and consists of two distinct layers. The upper silt layer is about $2.5 \mathrm{~m}(8.2 \mathrm{ft})$ thick, and the lower "caliche" layer is about $0.5 \mathrm{~m}(1.64 \mathrm{ft})$ thick and varies from gravel to sand,to silt with a calcium carbonate cemented matrix. At the 216-Z-1A Tile Field, the CCU occurs at approximately 121 to $138 \mathrm{ft}$ bgs. The RI borehole drilled to investigate the 216-A-8 Crib did not encounter the CCU because it is not present in the vicinity of the 216-A-8 Crib.

\section{B.1.4 Hanford formation}

The Hanford formation is the informal stratigraphic name used to describe the Pleistocene cataclysmic flood deposits in the Pasco Basin (DOE/RL 2002). The Hanford formation consists predominantly of unconsolidated sediments that range from boulder-size gravel to sand, silty sand, and silt. The sorting ranges from poorly sorted (for gravel facies) to well sorted (for fine sand and silt facies). The Hanford formation is divided into three main facies associations: interbedded sand to silt-dominated (formerly called the Touchet beds or slackwater facies); sand-dominated (formerly called the sanddominated flood facies); and gravel-dominated (formerly called the Pasco gravels), which have been further subdivided into 11 textural structural lithofacies (DOE/RL 2002). Beneath the representative waste sites, and where carbon tetrachloride has migrated beyond the boundaries of the known carbon tetrachloride disposal sites, the Hanford formation includes all three facies associations. The graveldominated facies are cross-stratified, coarse-grained sands and gravel to boulder gravel. The gravel is uncemented and matrix poor. The sand-dominated facies are well-stratified fine- to coarse-grained sand and granule gravel. Silt in these facies is variable and may be interbedded with the sand. Where the sand and silt content is low in the gravel-dominated facies, an open framework texture is common. Clastic dikes are common in the Hanford formation but rare in the Ringold Formation (DOE/RL 1999, 2002). They appear as vertical to subvertical sediment-filled structures, especially within sand- and siltdominated units. The two RI boreholes at the 216-Z-9 Trench and the RI borehole at the 216-A-8 Crib penetrated into the Hanford formation. In general, from shallowest to deepest, the Hanford formation units encountered beneath the 200 West Area included an upper fines unit (HFUF), the upper graveldominated sequence $(\mathrm{H} 1)$, a sand-dominated sequence $(\mathrm{H} 2)$, and a lower gravel-dominated sequence (H3). Not all of these units are laterally continuous beneath the waste sites.

The cataclysmic floodwaters that deposited sediments of the Hanford formation locally reshaped the topography of the Pasco Basin. The floodwaters deposited a thick sand and gravel bar (Cold Creek Bar) that constitutes the higher southern portion of the 200 Areas, informally known as the 200 Areas Plateau. In the waning stages of the Ice Age Floods, these floodwaters also eroded a channel north of the 200 Areas in the area currently occupied by West Lake and the former Gable Mountain Pond. Both preHanford formation erosion and the floodwaters removed all of the Ringold Formation from this area and deposited Hanford formation sediments directly over basalt.

\section{B.1.5 Surficial Deposits}

Surficial deposits include Holocene eolian sheets of sand that form a thin veneer over the Hanford formation across the site, except in localized areas where the deposits are absent. Surficial deposits consist of very fine- to medium-grained sand to occasionally silty sand. Silty deposits less than $1 \mathrm{~m}$ 
(approximately $3 \mathrm{ft}$ ) thick also have been documented at some open trench waste sites where fine-grained, windblown material settled out through standing water over many years (DOE/RL 1999, Appendix F). Fill material was placed in and over some waste sites during construction and for contamination control. The fill consists of reworked Hanford formation sediments and/or surficial sand and silt.

\section{B.2 Vadose Zone Geology Specific to the 216-Z-1A Tile Field}

The 216-Z-1A Tile Field is located in the 200 West Area within a north-south secondary flood channel. The surface elevation around this site is approximately $207 \mathrm{~m}$ (679 ft). Stratigraphic units of interest are, in descending order, the Hanford formation, the CCU, and the Ringold Formation Unit 5. The top of the unconfined aquifer is in the silty sandy gravels of Ringold Formation Unit 5, and the base of the aquifer is the top of Ringold Formation lower mud (Unit 8). The stratigraphy in the vicinity of the 216-Z-1A Tile Field is based on the borehole log from well 299-W18-7, located adjacent to the tile field. The Hanford formation upper gravel-dominated sequence (H1) was encountered from the ground surface to approximately $18 \mathrm{~m}(59 \mathrm{ft}) \mathrm{bgs}$, underlain by the Hanford formation sand-dominated sequence (H2, 18 to $29 \mathrm{~m}$ [ 59 to $95 \mathrm{ft}$ ] bgs [note that a silt layer occurs between about 25 and $27 \mathrm{~m}$ ( 85 and $90 \mathrm{ft} \mathrm{bgs})$ ]), the Hanford formation lower gravel-dominated sequence (H3, 29 to $37 \mathrm{~m}$ [95 to $121 \mathrm{ft}$ ] bgs), the CCU silt and caliche units from approximately 37 to $42 \mathrm{~m}$ (121 to $138 \mathrm{ft}$ ) bgs, and the gravelly Ringold Formation Unit 5, below $42 \mathrm{~m}$ (138 ft) bgs.

\section{B.3 Vadose Zone Geology Specific to the 216-Z-9 Trench}

The 216-Z-9 Trench is located in the 200 West Area within a north-south secondary flood channel. The surface elevation of this site is approximately $201 \mathrm{~m}(660 \mathrm{ft})$. Stratigraphic units of interest are, in descending order, the Hanford formation, the CCU, and the Ringold Formation Unit 5. The top of the unconfined aquifer is in the silty sandy gravel of Ringold Formation Unit 5, and the base of the aquifer is the top of Ringold Formation lower mud (Unit 8). The stratigraphy is based on the borehole log from well 299-W15-46, which was drilled on the south side of the trench (DOE/RL 2007, Figure 3-7). The upper $1.2 \mathrm{~m}$ (4 ft) of this well encountered backfill material used for drill pad construction, which comprised crushed rock, sand, and silt. Below the drill pad fill, fine-grained sands and silts of the Hanford formation upper fines (HFUF) were encountered to a depth of $6 \mathrm{~m}(20 \mathrm{ft}$ ). Below the HFUF, to a depth of $10.5 \mathrm{~m}(34.5 \mathrm{ft})$, the sediments encountered were the upper gravels of the Hanford formation (H1). These sediments were dark gray fine to coarse sand and gravelly sand. The interval from 10.5 to $33 \mathrm{~m}$ ( 34.5 to $108.5 \mathrm{ft}$ ) bgs consisted of sediments from the sand-dominated sequence of the Hanford formation (H2). A layer of dense, well-compacted, dark brown silt was encountered from 19.8 to $20.4 \mathrm{~m}$ (65 to $67 \mathrm{ft}$ ) bgs. The interval from 33 to $36.1 \mathrm{~m}$ (108.5 to $118.5 \mathrm{ft}$ ) bgs consisted of the CCU. Dense, well-compacted, dark brown silt and sand comprising the upper silt dominated facies of the CCU were encountered from 33 to $35.5 \mathrm{~m}$ ( 108.5 to $116.5 \mathrm{ft}$ ) bgs. The CCU caliche was encountered from 35.5 to $36.1 \mathrm{~m}$ (116.5 to $118.5 \mathrm{ft}$ ) bgs. The interval from 36.1 to $69.5 \mathrm{~m}$ (118.5 to $228 \mathrm{ft}$ ) bgs consisted of grayish brown sandy gravel with variable silt, sand, and sandy gravel of the Ringold Formation Unit 5.

The stratigraphy from the slant well (299-W15-48) drilled at the 216-Z-9 Trench is similar to that of well 299-W15-46 (DOE/RL 2007, Figure 3-8). From a contaminant migration perspective, the most important units are the silt layer that occurs within the Hanford formation at approximately 18 to $19 \mathrm{~m}$ (60 to $62 \mathrm{ft}$ ) bgs and the CCU that occurs at approximately 32 to $35 \mathrm{~m}$ (105 to $115 \mathrm{ft}$ ) bgs. The depths for these units are very similar to those determined in well 299-W15-46. 


\section{B.4 Vadose Zone Geology Specific to the 241-Z-361 Settling Tank}

The 241-Z-361 Settling Tank is located approximately $35 \mathrm{~m}(115 \mathrm{ft})$ north of the 216-Z-1A Tile Field in the 200 West Area. The surface elevation and hydrogeologic conditions at this representative waste site are the same as those for the adjacent 216-Z-1A Tile Field (Section B.2).

\section{B.5 Vadose Zone Geology Specific to the 216-A-8 Crib}

The 216-A-8 Crib is located approximately $177 \mathrm{~m}(580 \mathrm{ft})$ east of the A Tank Farm in the 200 East Area, at a surface elevation of approximately $198 \mathrm{~m}(650 \mathrm{ft})$. The stratigraphic unit of interest is the Hanford formation. The top of the unconfined aquifer is in the Ringold Formation Unit 9, and the base of the aquifer is the top of the basalt. The stratigraphy is based on the log from Borehole C4545, which was drilled through the crib (DOE/RL 2007, Figure 3-8). The upper portion of Borehole C4545 encountered $0.5 \mathrm{~m}(1.5 \mathrm{ft})$ of crushed rock, used to construct the drill pad, overlying the crib construction backfill consisting of $1.4 \mathrm{~m}(4.5 \mathrm{ft})$ of gravelly sand, $2.1 \mathrm{~m}(7.0 \mathrm{ft})$ of sand, and $1.8 \mathrm{~m}(6.0 \mathrm{ft})$ of very coarse gravel. The interval beneath the crib construction backfill, extending from 5.8 to $54.3 \mathrm{~m}$ (19.0 to $178.0 \mathrm{ft}$ ) bgs, consists of well-stratified, very fine- to coarse-grained sands belonging to the sand-dominated sequence of the Hanford formation (H2). Several intervals within Hanford formation $(\mathrm{H} 2)$ contain finergrained silty sands. The interval from 54.3 to $74.8 \mathrm{~m}$ (178.0 to $245.5 \mathrm{ft}$ ) bgs consists of the graveldominated sequence of the Hanford formation (H3). These gravels consist of poorly sorted, angular to sub-rounded heterolithic cobbles (basalts and other dominantly igneous lithologies). The interval from 74.8 to $80.6 \mathrm{~m}$ ( 245.5 to $264.5 \mathrm{ft}$ ) bgs (total depth) consists of sandy gravels of the Ringold Formation Unit 9. These sediments consist of clast- to matrix-supported pebble ( 2 to $64 \mathrm{~mm}$ [0.008 to $2.5 \mathrm{in}$.]) to cobble (64 to $256 \mathrm{~mm}$ [ 2.5 to $10 \mathrm{in}$.]) heterolithic gravels with a fine- to coarse-grained sandy matrix. Lenticular sand and silt interbeds also are characteristic of the Ringold Formation Unit 9. The stratigraphy underlying the 216-A-8 Crib is shown in Figure 3-7 of DOE/RL (2006). The stratigraphy generally is consistent with the borehole logs from other wells adjacent to the crib.

\section{B.6 Vadose Zone Geology Specific to the 216-Z-8 French Drain}

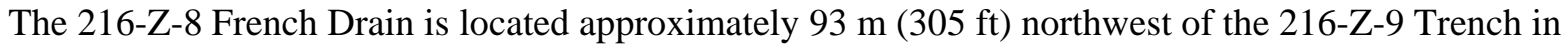
the 200 West Area. The surface elevation and hydrogeologic conditions at this waste site are the same as those for the adjacent 216-Z-9 Trench (Section B.3)

\section{B.7 Vadose Zone Geology Specific to the 216-Z-10 Injection/Reverse Well}

The 216-Z-10 Injection/Reverse Well is approximately $30.5 \mathrm{~m} \mathrm{(100} \mathrm{ft)} \mathrm{east} \mathrm{of} \mathrm{the} \mathrm{231-Z} \mathrm{Building} \mathrm{in}$ the 200 West Area. The 216-Z-10 Injection/Reverse Well also has been known as the 231-W Reverse Well, 231-W-151 Dry Well or Reverse Well, 231-Z Well, 299-W15-51, 231-W-150, and 216-Z-2. The surface elevation is approximately $204 \mathrm{~m}(670 \mathrm{ft})$.

Well 299-W15-59 is located $4.6 \mathrm{~m} \mathrm{(15} \mathrm{ft)} \mathrm{from} \mathrm{the} \mathrm{216-Z-10} \mathrm{Injection/Reverse} \mathrm{Well.} \mathrm{At} \mathrm{well}$ 299-W15-59 the borehole geophysics reported the CCU fine-grained sediment between 35 and $37.5 \mathrm{~m}$ (115 and $123 \mathrm{ft}$ ). Between 37.8 and $42.1 \mathrm{~m}$ (123 and $138 \mathrm{ft}$ ) results are characteristic of the carbonate paleosols of the CCU. The Ringold formation is present from $42.1 \mathrm{~m}(138 \mathrm{ft})$ to groundwater (DOE-EM/GJ 2005). 


\section{B.8 References}

Barnett DB, BA Williams, CJ Chou, and MJ Hartman. 2006. Post-Closure RCRA Groundwater Monitoring Plan for the 216-S-10 Pond and Ditch. PNNL-15731, Pacific Northwest National Laboratory, Richland, Washington.

DOE-EM/GJ. 2005. Log Data Report for 299-W15-59 (A7360), Stoller Hanford Office. DOE-EM/GJ918, U.S. Department of Energy, Richland Operations Office, Richland, Washington.

DOE/RL. 1999. 200 Areas Remedial Investigation/Feasibility Study Implementation Plan Environmental Restoration Program. DOE/RL-98-8, Rev. 0, U.S. Department of Energy, Richland Operations Office, Richland, Washington.

DOE/RL. 2002. Standardized Stratigraphic Nomenclature for Post Ringold Formation Sediments Within the Central Pasco Basin. DOE/RL-2002-39, U.S. Department of Energy, Richland Operations Office, Richland, Washington.

DOE/RL. 2007. Remedial Investigation Report for the Plutonium/Organic-Rich Process

Condensate/Process Waste Group Operable Unit: Includes the 200-PW-1, 200-PW-3, and 200-PW-6 Operable Units. DOE/RL-2006-51, Rev. 0, prepared for the U.S. Department of Energy, Richland, Washington.

Williams BA, BN Bjornstad, R Schalla, and WD Webber. 2001. Revised Hydrogeology for the Suprabasalt Aquifer System, 200-East Area and Vicinity, Hanford Site, Washington. PNNL-12261, Pacific Northwest National Laboratory, Richland, Washington.

Williams BA, BN Bjornstad, R Schalla, and WD Webber. 2002. Revised Hydrogeology for the Suprabasalt Aquifer System, 200-West Area and Vicinity, Hanford Site, Washington. PNNL-13858, Pacific Northwest National Laboratory, Richland, Washington. 
Appendix C

Geochemistry of Plutonium and Americium 


\section{Appendix C}

\section{Geochemistry of Plutonium and Americium}

This appendix provides a brief summary of the key geochemical processes affecting the mobility of plutonium and americium in sediments. ${ }^{(1)}$ The information in this section is a slightly updated version of what has been previously described (Cantrell et al. 2007) and subsequently summarized from more detailed reviews (EPA 1999b, 2004; Napier et al. 2005).

The concentrations and mobility of contaminants in surface and subsurface geologic systems ${ }^{(2)}$ are controlled by numerous hydrologic and geochemical processes. These primarily include the amount and nature of contaminants present at the source; the rate of their release from the source; hydrologic factors, such as dispersion, advection, and dilution; and geochemical processes, such as aqueous complexation, oxidation/reduction (redox), adsorption/desorption and ion exchange, precipitation/dissolution, diffusion, colloid-facilitated transport, and anion exclusion. Further background information regarding these geochemical processes is given by Garrels and Christ (1965), Baes and Mesmer (1976), Yariv and Cross (1979), Stumm and Morgan (1981), Morel (1983), Nordstrom and Munoz (1985), Sposito (1989, 1994), Langmuir (1997), Deutsch (1997), Appelo and Postma (2005), and others, and the references cited therein.

Adsorption/desorption (including ion exchange) and precipitation/dissolution (including coprecipitation $^{(3)}$ ) are considered the most important geochemical processes affecting the interaction of contaminants with sediments and soils. Adsorption/desorption will likely be the key geochemical process controlling contaminant retardation in areas where trace concentrations of dissolved contaminants exist, such as those associated with far-field environments of disposal facilities. Precipitation/dissolution is more likely to be an important process where elevated concentrations of dissolved radionuclides exist, such as in the near-field environment of disposal sites or where steep $\mathrm{pH}$, redox, or concentration gradients exist. Throughout this appendix, sorption will be used as a generic term devoid of mechanism, and used to describe the partitioning of dissolved aqueous-phase constituents to a solid phase. When a contaminant is associated with a geologic material, however, it is commonly not known if the contaminant is adsorbed onto the surface of the solid, absorbed into the structure of the solid, precipitated as a three-dimensional molecular structure on the surface of the solid, or partitioned into the organic matter (Sposito 1989). The term sorption encompasses all of the above processes.

\footnotetext{
(1) The terms soil and sediment have specific meanings, depending on the reader's technical discipline. For example, soil is often limited to referring to the top layer of the Earth's surface, suitable for plant life. The term sediment is usually reserved for transported and deposited particles derived from soil, rocks (such as the sediments at the Hanford Site), or biological material. In this appendix, sediment is also used as a general term to refer to all unconsolidated geologic materials. Soil from the Hanford perspective should refer to unconsolidated material at/near ground surface that supports plant life.

${ }^{(2)}$ Surface and subsurface systems include soils, sediments, surface waters, sediment and soil pore waters, groundwaters, and geological rock formations.

${ }^{(3)}$ Coprecipitation refers to the incorporation (absorption) of a trace concentration of element during precipitation of a phase that does not normally contain that element as a required structural component.
} 


\section{C.1 Calculation of Eh-pH Diagrams}

The Eh and $\mathrm{pH}$ conditions and associated complexation reactions are key parameters for understanding the environmental behavior of plutonium and americium. Pourbaix (Eh-pH) diagrams are used to illustrate the influence that each of these parameters has on the geochemistry of plutonium and americium. Figure C.1 shows those Eh and $\mathrm{pH}$ regions on an Eh-pH diagram that are considered oxidizing, reducing, and transition environments, such as mildly reducing, in the following discussions. Included on the diagram is a dark yellow area (ellipse) that shows the general Eh-pH region expected for pore water in the vadose zone and groundwater from the upper unconfined aquifer not affected by waste release. Generally, the Eh values for vadose zone pore waters are expected to be oxic.

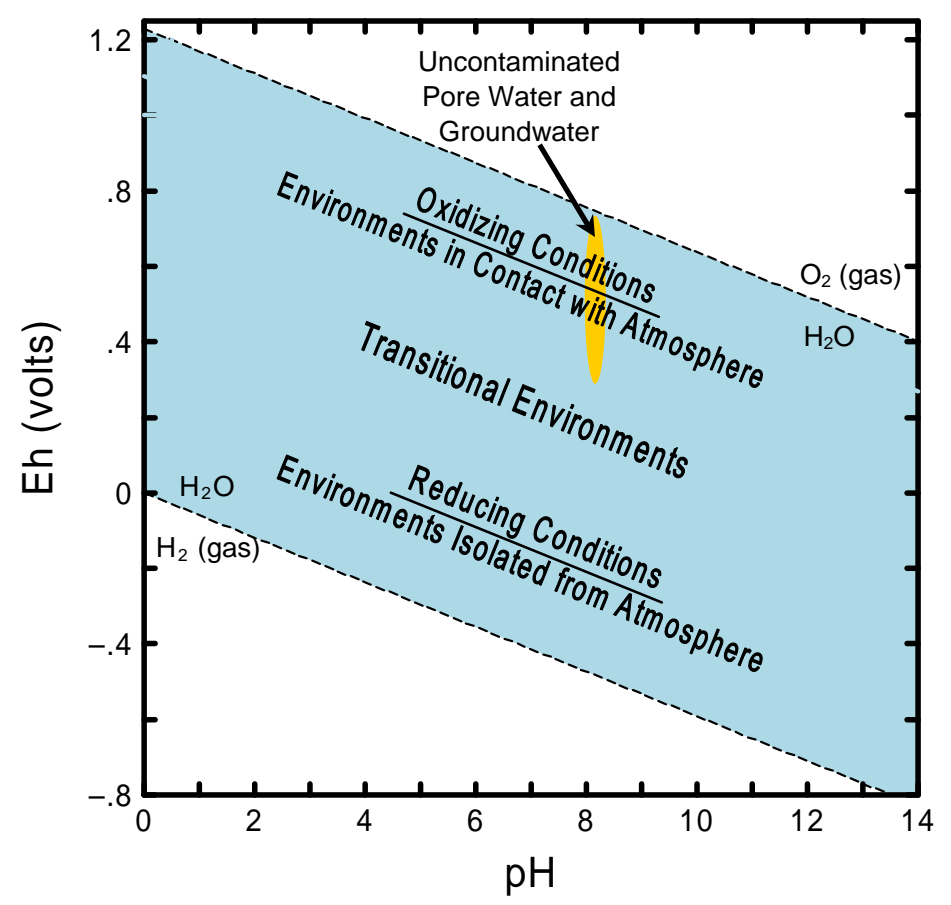

Figure C.1. Approximate Position of Some Natural Environments as a Function of $\mathrm{pH}$ and Eh Conditions. The dark yellow area shows the general Eh-pH region expected for pore water from vadose zone and groundwater from the upper unconfined aquifer not affected by waste release.

The theory behind the calculation of Eh-pH predominance diagrams is discussed by Garrels and Christ (1965), Nordstrom and Munoz (1985), Langmuir (1997), and others. The Eh-pH diagrams were calculated at $25^{\circ} \mathrm{C}(298 \mathrm{~K})$ and 1 atm pressure using the The Geochemist's Workbench ${ }^{\circledR}$ (Version 6.0.4) software package and the expanded thermodynamic database file "thermo.com.V8.R6+.dat" provided with the software package. The Lawrence Livermore National Laboratory (LLNL) developed the thermodynamic database file originally for use with the EQ3/6 geochemical model. This database includes the thermodynamic values for the americium species given in the extensive reviews by Silva et al. (1995). However, the database file predates publication of the extensive reviews of thermodynamic plutonium by Lemire et al. (2001) and related data updates in Guillaumont et al. (2003). 
The Eh-pH diagrams presented below are meant for demonstration purposes only to show general aspects of the dominant aqueous species and potential solubility controls for contaminants of interest (COI) with respect to $\mathrm{pH}, \mathrm{Eh}$, and presence of inorganic complexing anions. To show the impact of dissolved bicarbonate $\left(\mathrm{HCO}_{3}{ }^{-}\right)$on the calculated aqueous speciation, the total bicarbonate activity was assumed to equal approximately twice the total alkalinity (given as $67.5 \mathrm{mg} / \mathrm{L} \mathrm{CO}_{3}{ }^{2-}$ ) measured for an uncontaminated groundwater from the Hanford Site by Kaplan et al. (1996). The Geochemist's Workbench ${ }^{\circledR}$ software package calculates Eh $\mathrm{pH}$ diagrams for the speciation of a dissolved element (e.g., uranium) using input values of activity, which is often referred to as an effective concentration (Krauskopf 1979), for the concentration of the element of interest. The following Eh-pH diagrams are used to display the stability fields for the dominant aqueous species and potential solubility-controlling solid(s) for each contaminant of interest (COI) based on available thermodynamic databases. Therefore, the concentrations of COIs, cations, and anions were used for the sake of simplicity as activity input values for the Eh-pH speciation calculations. Because thermodynamic data are not available for Pu and Am complexes with TBP, DBBP, $\mathrm{DBP}$, and MBP, the impact of these compounds is not included in these calculations.

Each Eh-pH diagram contains dashed black lines from coordinates (Eh $1.2 \mathrm{~V}-\mathrm{pH}$ 0) to (Eh $0.4 \mathrm{~V}-\mathrm{pH} \mathrm{14}$ ) and from (Eh $0.0 \mathrm{~V}-\mathrm{pH} 0$ to $\mathrm{Eh}-0.8 \mathrm{~V}-\mathrm{pH} 14)$ that represent the Eh-pH boundaries for the dissociation of water to its gaseous components at $25^{\circ} \mathrm{C}$ and 1 atm pressure. At Eh-pH values above the upper black dashed line, water breaks down to oxygen gas. At Eh-pH values below the lower black dashed line, water breaks down to hydrogen gas. The redox conditions for essentially all environmental systems occur in the region within these water-stability limits. All diagrams were calculated based on activity of $10^{-8} \mathrm{M}$. This activity was selected to represent trace concentrations. At trace concentrations, the stability relationships between dissolved species do not change significantly with changes in the concentrations of the metal or radionuclide of interest. However, changes in the concentrations of the metal or radionuclide of interest can have a significant impact on the stability fields of solid phases. For nitrate, an activity of $10^{-2} \mathrm{M}$ was used to calculate the diagrams. This concentration was arbitrarily selected to more realistically reflect values that occur in the vadose zone pore waters impacted by process wastes.

\section{C.2 Plutonium-239/240}

The geochemical behavior of plutonium in natural systems has been reviewed by Ames and Rai (1978), Onishi et al. (1981), EPA (1999b), and others. Plutonium-239 and ${ }^{240} \mathrm{Pu}$ have half-lives ( $\left.\mathrm{t}_{1 / 2}\right)$ of $2.411 \times 10^{4}$ and 6,564 years, respectively. Plutonium can exist in the +3 (III), +4 (IV), +5 (V), and +6 (VI) oxidation states under most environmental conditions (Allard and Rydberg 1983). Plutonium can exist in $+4,+5$, and +6 oxidation states under oxidizing conditions (Keeney-Kennicutt and Morse 1985), whereas the +3 and +4 oxidation states can exist under reducing conditions. However, a number of investigators believe that $\mathrm{Pu}(\mathrm{V})$ is the dominant oxidation state of plutonium under oxidizing conditions (Nelson and Orlandini 1979; Aston 1980; Bondietti and Trabalka 1980; Rai et al. 1980b).

The dominant aqueous species of plutonium are shown as a function of Eh-pH conditions in Figure C.2. The Eh-pH diagram was calculated using a total activity of $1 \times 10^{-8} \mathrm{M}$ dissolved plutonium. As shown in Figure C.2, $\mathrm{Pu}(\mathrm{V})$ species $\mathrm{PuO}_{2}{ }^{+}$and $\mathrm{PuO}_{2} \mathrm{OH}^{0}(\mathrm{aq})$ and the $\mathrm{Pu}(\mathrm{VI})$ species $\mathrm{PuO}_{2}\left(\mathrm{CO}_{3}\right)_{2}{ }^{2-}$ calculate to be dominant at oxidizing conditions from acidic to basic $\mathrm{pH}$ values, respectively. The $\mathrm{Pu}(\mathrm{IV})$ species $\mathrm{Pu}(\mathrm{OH})_{4}{ }^{0}(\mathrm{aq})$ is predicted to have a large stability range extending above near-neutral $\mathrm{pH}$ values at moderately oxidizing conditions to $\mathrm{pH}$ values greater than 8 under reducing conditions. The $\mathrm{Pu}$ (III) species, such as $\mathrm{Pu}^{3+}$, would be dominant up to $\mathrm{pH}$ values of approximately 8.5 under reducing 
conditions. Dissolved plutonium can form stable complexes with a variety of inorganic and organic ligands (Cleveland 1979). Plutonium is expected to form stronger complexes with dissolved carbonate, sulfate, phosphate, and fluoride, relative to those with ligands such as chloride and nitrate. Plutonium can also form strong mixed hydroxy-carbonate ligand complexes [e.g., $\mathrm{Pu}(\mathrm{OH})_{2}\left(\mathrm{CO}_{3}\right)_{2}{ }^{2-}$ ] (Yamaguchi et al. 1994; Tait et al. 1995).

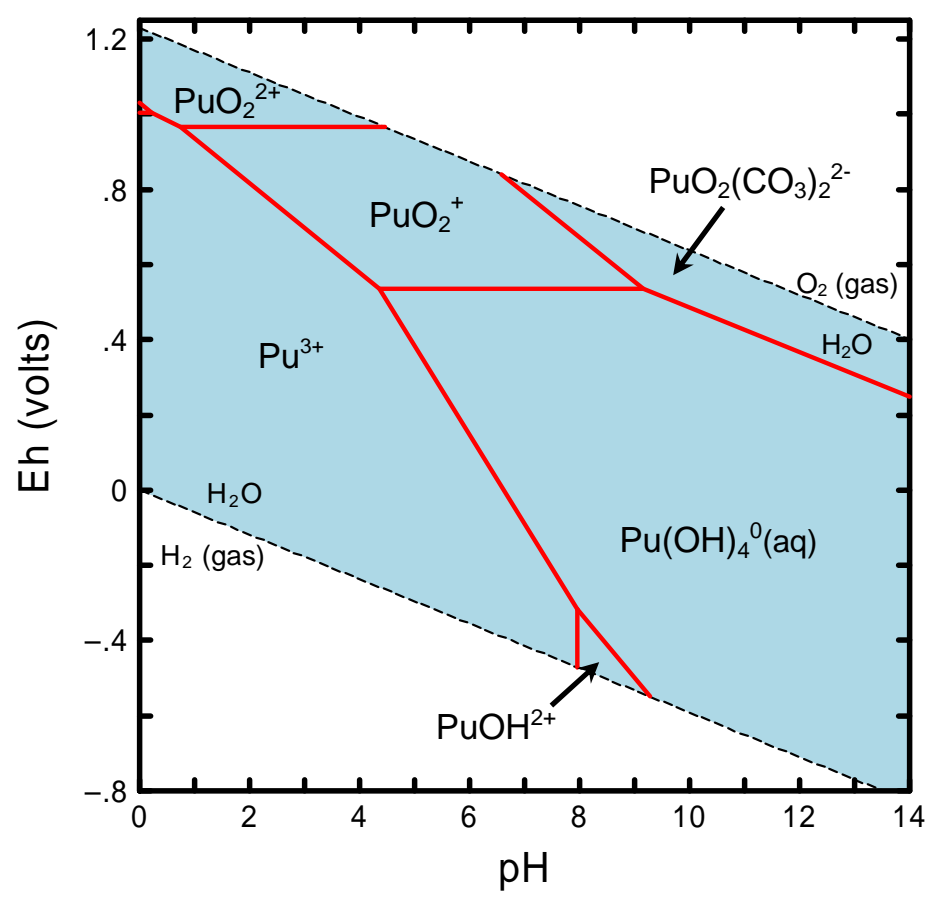

Figure C.2. Eh-pH Diagram Showing Dominant Aqueous Species of Plutonium. (Diagram was calculated at a total activity of $1 \times 10^{-8} \mathrm{M}$ dissolved plutonium at $25^{\circ} \mathrm{C}$.)

Several studies show that plutonium associated with sediments and particulate organic material is present in the +4 oxidation state (Nelson and Lovett 1980; Silver 1983; Nelson et al. 1987). Laboratory studies conducted by Rai et al. (1980a), Delegard (1987), and Yamaguchi et al. (1994) indicate that a freshly precipitated amorphous $\mathrm{PuO}_{2} \bullet \mathrm{xH}_{2} \mathrm{O}$ phase controls the maximum solubility concentration of plutonium in environmental systems. Under oxidizing conditions, the precipitation of amorphous $\mathrm{PuO}_{2} \bullet \mathrm{xH}_{2} \mathrm{O}$ may control the maximum concentrations of dissolved plutonium at approximately $10^{-8} \mathrm{~mol} / \mathrm{L}$ or less in sediments. Figure C.3 shows the Eh-pH region (tan-colored area) in which $\mathrm{PuO}_{2}$ calculates to be oversaturated at $25^{\circ} \mathrm{C}$ for a total activity of $1 \times 10^{-16} \mathrm{M}$ dissolved plutonium based on the available thermodynamic data. 


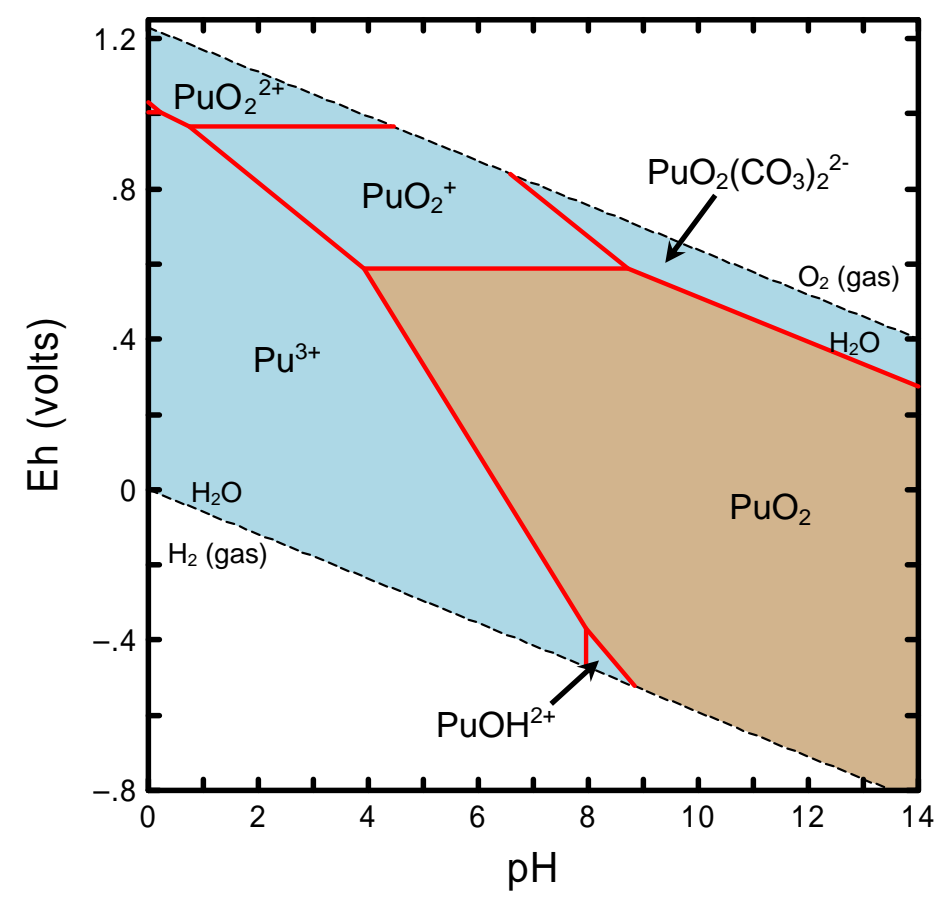

Figure C.3. Diagram Showing Eh-pH Region (tan colored) that Calculates to be Oversaturated with Respect to the Solubility of $\mathrm{PuO}_{2}$. (Diagram was calculated at a total activity of $1 \times 10^{-16} \mathrm{M}$ dissolved plutonium at $25^{\circ} \mathrm{C}$.)

Kaplan et al. (2006a) measured the dissolved concentrations and oxidation state transformations of plutonium as a function of $\mathrm{pH}$ in sorption and desorption experiments with a sandy-clay-loam sediment taken from the field lysimeter study described in Kaplan et al. (2004, 2006b). The sediment used for the field lysimeter study was collected from the vadose zone at the Savannah River Site (SRS) near Aiken, South Carolina. For the sorption study, sediment was taken from a lysimeter that did not receive any plutonium source material. When $\mathrm{Pu}(\mathrm{V})$ was added to a suspension of this uncontaminated sediment, the resulting sorbed plutonium was found to have been reduced completely to the $\mathrm{Pu}(\mathrm{IV})$ oxidation state, whereas the dissolved plutonium was present as $\geq 94 \% \mathrm{Pu}(\mathrm{V}), \leq 6 \% \mathrm{Pu}(\mathrm{VI})$, and $\leq 1 \% \mathrm{Pu}(\mathrm{IV})$. Kaplan et al. (2006a) attributed the reduction of the sorbed plutonium to the reduction capacity of this sediment, which likely resulted from the $\mathrm{Fe}(\mathrm{II})$ - or $\mathrm{Fe}$ (III)-containing minerals commonly identified in these sediments, such as ilmenite $\left(\mathrm{FeTiO}_{3}\right)$, biotite $\left[\mathrm{K}(\mathrm{Mg}, \mathrm{Fe})_{3}(\mathrm{Al}, \mathrm{Fe}) \mathrm{Si}_{3} \mathrm{O}_{10}(\mathrm{OH}, \mathrm{F})_{2}\right]$, magnetite $\left(\mathrm{Fe}_{3} \mathrm{O}_{4}\right)$, maghemite $\left(\gamma-\mathrm{Fe}_{2} \mathrm{O}_{3}\right)$, goethite $[\alpha-\mathrm{FeO}(\mathrm{OH})]$, and hematite $\left(\alpha-\mathrm{Fe}_{2} \mathrm{O}_{3}\right)$, or microbial activity. For the desorption measurements, Kaplan et al. (2006a) used a sediment sample that was previously contaminated from contact with a $\mathrm{Pu}^{\mathrm{IV}}\left(\mathrm{NO}_{3}\right)_{4}$ source disk for 24 years in the lysimeter study. In a series of batch desorption tests with the plutonium-contaminated sediment at different suspension $\mathrm{pH}$ values from 2.51 to 7.95 , they measured approximately an order-of-magnitude increase in the concentration of dissolved plutonium with a decrease of one $\mathrm{pH}$ unit at near-neutral $\mathrm{pH}$ conditions. The desorbed, dissolved plutonium was present as $\geq 96 \% \mathrm{Pu}(\mathrm{V} / \mathrm{VI})$. This trend in dissolved plutonium concentrations as a function of $\mathrm{pH}$ was nearly identical to the trend for the solubility for $\mathrm{PuO}_{2}(\mathrm{am})$ (amorphous $\mathrm{PuO}_{2}$ ) given in the literature, except that the desorption concentrations were lower by a fixed amount. Although they could not rule the possibility of plutonium sorption occurring in their desorption experiments, Kaplan et al. (2006a) proposed that the measured desorption behavior was likely due to 
dissolution of a solid form of plutonium that was more crystalline and less soluble than the solubility data in the literature for the $\mathrm{PuO}_{2}(\mathrm{am})$-water system.

Dissolved plutonium in the environment is typically present at less than $10^{-15} \mathrm{~mol} / \mathrm{L}$ (EPA 1999b). This indicates that adsorption may be the main process affecting the retardation of plutonium in sediments. Plutonium is known to adsorb strongly to a variety of sediment components, including clays, oxides, hydroxides, oxyhydroxides, aluminosilicates and organic matter (see review in EPA 1999b and references therein). The quantity and quality of plutonium adsorption studies conducted with Hanford sediment are much less than those available for many other contaminants of interest at the Hanford Site (Cantrell et al. 2003). The available data indicate for Hanford sediments that plutonium will be fairly immobile except at very low pH values or high EDTA concentrations (Cantrell et al. 2003).

Several studies show that plutonium present in the higher +5 and +6 oxidation states may be reduced to the +4 state by adsorption onto iron-oxide surfaces containing $\mathrm{Fe}$ (II) (EPA 1999b). The $\mathrm{K}_{\mathrm{d}}$ values for plutonium can range typically over several orders of magnitude, depending on the properties of the substrate, $\mathrm{pH}$, and the composition of solution (Baes and Sharp 1983; Coughtrey et al. 1985; Thibault et al. 1990). The $K_{d}$ values listed for plutonium in the compilation by Thibault et al. (1990) range from 27 to $190,000 \mathrm{~mL} / \mathrm{g}$. However, EPA (1999a) cautions that measurements resulting in very large $\mathrm{K}_{\mathrm{d}}$ values may have been compromised by precipitation processes.

Adsorption studies indicate that the presence of increasing concentrations of ligands typically decrease plutonium adsorption (EPA 1999b). If no complexing ligands are present, the adsorption of plutonium in general increases with increasing $\mathrm{pH}$ from about $\mathrm{pH} 5$ to 9 . At $\mathrm{pH}$ values of 7 and greater, concentrations of dissolved carbonate and hydroxide will decrease the adsorption of plutonium and increase its mobility in sediments as a result of the formation of strong mixed ligand complexes with plutonium (EPA 1999b). The laboratory study by Sanchez et al. (1985) showed that increasing carbonate concentrations decreased the adsorption of $\mathrm{Pu}(\mathrm{IV})$ and $\mathrm{Pu}(\mathrm{V})$ on the surface of goethite $[\alpha-\mathrm{FeO}(\mathrm{OH})]$. At low $\mathrm{pH}$ conditions in the presence of high concentrations of dissolved organic carbon, plutonium-organic complexes may control the adsorption and mobility of plutonium in sediments (EPA 1999b).

\section{C.3 Americium-241}

The environmental behavior of americium has been reviewed by Ames and Rai (1978), Onishi et al. (1981), Coughtrey et al. (1984), Silva and Nitsche (1995), and others. Americium-241 has a half-life (t $\left.\mathrm{t}_{1 / 2}\right)$ of 432.7 years (Tuli 2004). Moulin et al. $(1988,1992)$ review the aqueous speciation of Am(III) in natural waters and in the presence of humic substances in natural waters, respectively. Silva et al. (1995) have published an extensive, detailed critical review of the chemical thermodynamics of americium aqueous species and solids. Americium can exist in the $+3,+4,+5$, and +6 oxidation states; however, $\mathrm{Am}(\mathrm{III})$ is the most stable and important oxidation state in environmental systems. The higher oxidation states are strong oxidizing agents and stable only in systems containing no oxidizable compounds (Ames and Rai 1978).

Figure C.4 is an Eh-pH diagram that shows the dominant aqueous species of americium calculated at $25^{\circ} \mathrm{C}$ using a total activity of $1 \times 10^{-8} \mathrm{M}$ dissolved americium. Americium is present in the +3 oxidation state in all of the dominant species predicted to be stable for the Eh-pH region of environmental interest. The uncomplexed ion $\mathrm{Am}^{3+}$ is the dominant aqueous species at moderately to highly acidic conditions. At near-neutral to alkaline $\mathrm{pH}$ conditions, Am(III) carbonate complexes will dominate the aqueous 


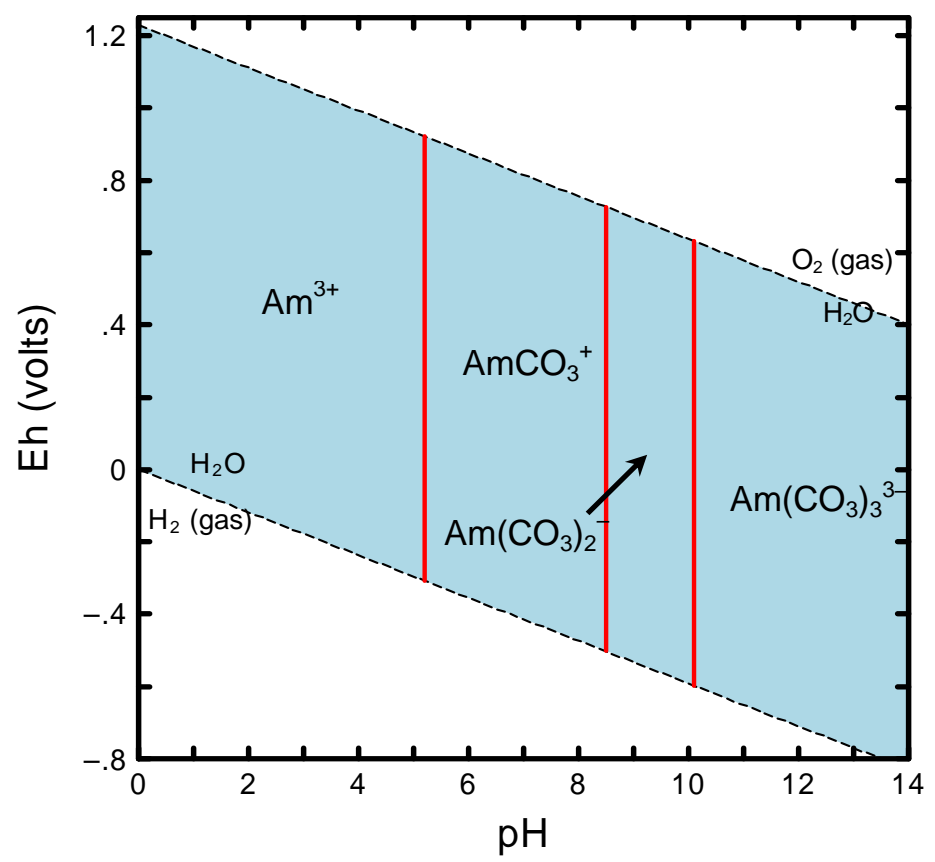

Figure C.4. Eh-pH Diagram Showing Dominant Aqueous Species of Americium. (Diagram was calculated at a total activity of $1 \times 10^{-8} \mathrm{M}$ dissolved americium at $25^{\circ} \mathrm{C}$.)

speciation of Am(III) (Figure C.4). Aqueous complexes, such as $\mathrm{Am}\left(\mathrm{CO}_{3}\right)_{3}{ }^{3-}$, will be increasingly important with increasing concentrations of dissolved carbonate at alkaline $\mathrm{pH}$ conditions. In sediments, studies indicate that Am(III) may also form strong complexes with humic substances (Moulin et al. 1992).

Concentrations of dissolved Am(III) in sediment environments may be controlled by the precipitation of hydroxide or carbonate solids in some systems (e.g., Silva 1984; Felmy et al. 1990; Vitorge 1992). In the Eh-pH region defined by the tan-colored area in Figure C.5, the solid $\mathrm{Am}(\mathrm{OH})_{3}$ calculates to be oversaturated based on the available thermodynamic data and the americium and ligand activities used for Figure C.4. Under these Eh-pH conditions (tan-colored area in Figure C.1), $\mathrm{Am}(\mathrm{OH})_{3}$ may precipitate to limit the maximum concentration of dissolved $\mathrm{Am}(\mathrm{III})$ in sediment. With increasing $\mathrm{pH}$ and dissolved carbonate concentrations, solids such as $\mathrm{AmOHCO}_{3}$ and $\mathrm{Am}_{2}\left(\mathrm{CO}_{3}\right)_{3}$ will be the likely solubility controls for dissolved Am(III). Vitorge (1992) used thermodynamic calculations to predict the stability domains of these Am(III) solids as a function of $\mathrm{pH}$ and dissolved carbonate.

Most sorption studies indicate that Am(III) readily sorbs to sediments, pure minerals, and crushed rock materials and exhibits high $\mathrm{K}_{\mathrm{d}}$ values that are often in the range of 1,000 to greater than $100,000 \mathrm{~mL} / \mathrm{g}$. Americium(III) is, therefore, considered one of the most immobile actinide elements in the environment. In their review of $\mathrm{K}_{\mathrm{d}}$ values for Hanford COIs, Cantrell et al. (2003) characterized americium as a contaminant with high $\mathrm{K}_{\mathrm{d}}$ values. An extensive review of Am(III) sorption studies is presented in EPA (2004). Americium(III) adsorption studies published before 1984 have been reviewed by Ames and Rai (1978), Onishi et al. (1981), and Coughtrey et al. (1984). The concentrations of dissolved Am(III) may be controlled in some sediment systems by precipitation of hydroxide or carbonate solids. Therefore, some sorption measurements resulting in very high $\mathrm{K}_{\mathrm{d}}$ values may have been affected by the precipitation of an Am(III) solid (EPA 1999a). 


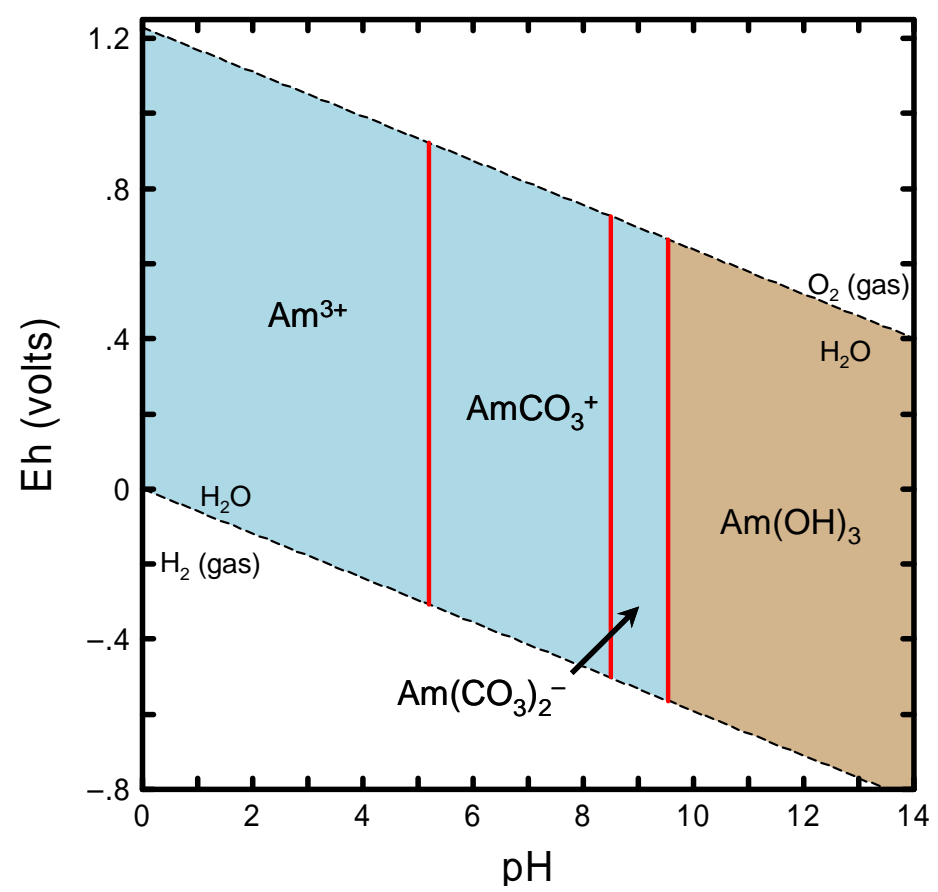

Figure C.5. Diagram Showing Eh-pH Region (tan colored) that Calculates to be Oversaturated with Respect to the Solubility of $\mathrm{Am}(\mathrm{OH})_{3}$. (Diagram was calculated at a total activity of $1 \times 10^{-8} \mathrm{M}$ dissolved americium at $25^{\circ} \mathrm{C}$.)

The adsorption of $\mathrm{Am}(\mathrm{III})$ is strongly $\mathrm{pH}$ dependent and increases with increasing $\mathrm{pH}$ with peak adsorption occurring between $\mathrm{pH}$ values of 5 and 6 (EPA 2004). This observed $\mathrm{pH}$ dependence is expected because the dominant aqueous species of $\mathrm{Am}$ (III) in the $\mathrm{pH}$ range of natural waters are primarily $\mathrm{Am}^{3+}$ and cationic carbonate and hydroxyl complexes at acidic and basic $\mathrm{pH}$ values, respectively (Figure C.4). Americium(III) is more mobile at low to moderate $\mathrm{pH}$ values where the net surface charge on minerals becomes more positive and in high ionic strength solutions. Adsorption of Am(III) might decrease in the $\mathrm{pH}$ values greater than 10 due to the dominance of the anionic complex $\mathrm{Am}\left(\mathrm{CO}_{3}\right)_{3}{ }^{3-}$ (Figure C.4). However, the tendency of Am(III) to strongly sorb to sediment and soil particles suggests that there is potential for colloid-facilitated transport of Am(III). For example, studies by Sheppard et al. (1979), Penrose et al. (1990), and Kaplan et al. (1994) have shown colloid-facilitated transport of Am(III) in certain systems.

\section{C.4 References}

Allard B and J Rydberg. 1983. "Behavior of Plutonium in Natural Waters." In Plutonium Chemistry, ACS Symposium Series 216, eds WT Carnall and GR Choppin, pp. 275-295. American Chemical Society, Washington, D.C.

Ames LL and D Rai. 1978. Radionuclide Interactions with Soil and Rock Media. Volume 1: Processes Influencing Radionuclide Mobility and Retention, Element Chemistry and Geochemistry, and Conclusions and Evaluations. EPA 520/6-78-007-a, U.S. Environmental Protection Agency, Las Vegas, Nevada.

Appelo CAJ and D Postma. 2005. Geochemistry, Groundwater and Pollution. 2nd ed. AA Balkema Publishers, New York. 
Aston SR. 1980. "Evaluation of the Chemical Forms of Plutonium in Seawater." Marine Chemistry 8(4):317-326.

Baes CF Jr. and RE Mesmer. 1976. The Hydrolysis of Cations. John Wiley \& Sons, Inc., New York.

Baes CF Jr. and RD Sharp. 1983. "A Proposal for Estimation of Soil Leaching Constants for Use in Assessment Models." Journal of Environmental Quality 12(1):17-28.

Bondietti EA and JR Trabalka. 1980. "Evidence for Plutonium(V) in an Alkaline, Freshwater Pond." Radiochemical and Radioanalytical Letters 43(3):169-176.

Cantrell KJ, RJ Serne, and GV Last. 2003. Hanford Contaminant Distribution Coefficient Database and Users Guide. PNNL-13895, Rev. 1, Pacific Northwest National Laboratory, Richland, Washington.

Cantrell KJ, JM Zachara, PE Dresel, and KM Krupka. 2007. Geochemical Processes Data Package for the Vadose Zone in the Single-Shell Tank Waste Management Area at the Hanford Site. PNNL-16663, Pacific Northwest National Laboratory, Richland, Washington.

Cleveland JM. 1979. The Chemistry of Plutonium. 2nd Printing. American Nuclear Society, LaGrange Park, Illinois.

Coughtrey PJ, D Jackson, CH Jones, P Kane, and MC Thorne. 1984. Radionuclide Distribution and Transport in Terrestrial and Aquatic Ecosystems. Volume 4: A Critical Review of Data. AA Balkema, Boston, Massachusetts.

Coughtrey PJ, D Jackson, and MC Thorne. 1985. Radionuclide Distribution and Transport in Terrestrial and Aquatic Ecosystems. Volume 6: A Compendium of Data. AA Balkema, The Netherlands.

Delegard CH. 1987. "Solubility of $\mathrm{PuO}_{2} \cdot \mathrm{xH}_{2} \mathrm{O}$ in Alkaline Hanford High-Level Waste Solution." Radiochimica Acta 41(1):11-21.

Deutsch WJ. 1997. Groundwater Geochemistry - Fundamentals and Applications to Contamination. Lewis Publishers, Boca Raton, Florida.

EPA. 1999a. Understanding Variation in Partition Coefficient, $K_{d}$, Values: Volume I. The $K_{d}$ Model, Methods of Measurement, and Application of Chemical Reaction Codes. EPA 402-R-99-004A, prepared for the U.S. Environmental Protection Agency, Washington, D.C., by the Pacific Northwest National Laboratory, Richland, Washington.

EPA. 1999b. Understanding Variation in Partition Coefficient, $K_{d}$, Values: Volume II. Review of Geochemistry and Available $K_{d}$ Values for Cadmium, Cesium, Chromium, Lead, Plutonium, Radon, Strontium, Thorium, Tritium $\left({ }^{3} \mathrm{H}\right)$, and Uranium. EPA 402-R-99-004B, prepared for the U.S. Environmental Protection Agency, Washington, D.C., by the Pacific Northwest National Laboratory, Richland, Washington. 
EPA. 2004. Understanding Variation in Partition Coefficient, $K_{d}$, Values: Volume III. Review of Geochemistry and Available $K_{d}$ Values for Americium, Arsenic, Curium, Iodine, Neptunium, Radium, and Technetium. EPA 402-R-04-002C, prepared for the U.S. Environmental Protection Agency, Washington, D.C., by the Pacific Northwest National Laboratory, Richland, Washington.

Felmy AR, D Rai, and RW Fulton. 1990. "The Solubility of $\mathrm{AmOHCO}_{3}(\mathrm{c})$ and the Aqueous Thermodynamics if the System $\mathrm{Na}^{+}-\mathrm{Am}^{3+}-\mathrm{HCO}_{3}{ }^{-}-\mathrm{CO}_{3}{ }^{2-}-\mathrm{OH}^{-}-\mathrm{H}_{2} \mathrm{O}$." Radiochimica Acta 50(4):193-204.

Garrels RM and CL Christ. 1965. Solutions, Minerals, and Equilibria. Freeman, Cooper and Co., San Francisco, California.

Guillaumont R, FJ Mompean, T Fanghänel, J Fuger, I Grenthe, V Neck, DA Palmer, and ML Rand. 2003. Chemical Thermodynamics, Volume 5: Chemical Thermodynamics of Uranium, Neptunium, Plutonium, Americium, and Technetium. Elsevier Science Publishing Company, New York.

Kaplan DI, PM Bertsch, DC Adriano, and KA Orlandini. 1994. "Actinide Association with Groundwater Colloids in a Coastal Plain Aquifer." Radiochimica Acta 66/67:181-187.

Kaplan DI, RJ Serne, AT Owen, J Conca, TW Wietsma, and TL Gervais. 1996. Radionuclide Adsorption Distribution Coefficients Measured in Hanford Sediments for the Low Level Waste Performance Assessment Project. PNNL-11485, Pacific Northwest Laboratory, Richland, Washington.

Kaplan DI, BA Powell, DI Demirkanli, RA Fjeld, FJ Molz, SM Serkiz, and JT Coates. 2004. "Influence of Oxidation States on Plutonium Mobility during Long-Term Transport through an Unsaturated Subsurface Environment.” Environmental Science \& Technology 38(19):5053-5058.

Kaplan DI, BA Powell, L Gumapas, JT Coates, RA Fjeld, and DP Diprete. 2006a. "Influence of pH on Plutonium Desorption/Solubilization from Sediment.” Environmental Science \& Technology 40(19):5937-5942.

Kaplan DI, DI Demirkanli, L Gumapas, BA Powell, RA Fjeld, FJ Molz, and SM Serkiz. 2006b. “Eleven Year Field Study of Pu Migration from Pu III, IV, and VI Sources.” Environmental Science \& Technology 40(2):443-448.

Keeney-Kennicutt WL and JW Morse. 1985. "The Redox Chemistry of $\mathrm{Pu}(\mathrm{V}) \mathrm{O}_{2}{ }^{+}$Interaction with Common Mineral Surfaces in Dilute Solutions and Seawater." Geochimica et Cosmochimica Acta 49(12):2577-2588.

Krauskopf KB. 1979. Introduction of Geochemistry. McGraw-Hill Book Company, New York, New York.

Langmuir D. 1997. Aqueous Environmental Geochemistry. Prentice Hall, Upper Saddle River, New Jersey.

Lemire RJ, J Fuger, H Nitsche, P Potter, MH Rand, J Rydbrg, K Spahiu, JC Sullivan, WJ Ullman, P Vitorge, and H Wanner. 2001. Chemical Thermodynamics, Volume 4: Chemical Thermodynamics of Neptunium and Plutonium. Elsevier Science Publishing Company, Inc., New York. 
Morel F. 1983. Principles of Aquatic Chemistry. John Wiley \& Sons, Inc., New York.

Moulin V, P Robouch, P Vitorge, and B Allard. 1988. "Environmental Behavior of Americium(III) in Natural Waters.” Radiochimica Acta 44/45(Pt.1):33-37.

Moulin V, J Tits, and G Ouzounian. 1992. "Actinide Speciation in the Presence of Humic Substances in Natural Water Conditions.” Radiochimica Acta 58/59(Pt.1):179-190.

Napier BA, KM Krupka, MM Valenta, and TJ Gilmore. 2005. Soil and Groundwater Sample Characterization and Agricultural Practices for Assessing Food Chain Pathways in Biosphere Models: Results for Three Geographical Locations. NUREG/CR-6881 (PNNL-15244), U.S. Nuclear Regulatory Commission, Washington, D.C.

Nelson DM and KA Orlandini. 1979. "Identification of $\mathrm{Pu}(\mathrm{V})$ in Natural Waters." In Radiological and Environmental Research Division Annual Report, Ecology, January-December 1979, ANL-79-65, Pt. 3, pp. 57-59. Argonne National Laboratory, Argonne, Illinois.

Nelson DM and MB Lovett. 1980. "Measurements of the Oxidation State and Concentration of Plutonium in Interstitial Waters in the Irish Sea." In Impacts of Radionuclide Releases into the Marine Environment, ed IAEA Staff, pp. 105-118. International Atomic Energy Agency (IAEA), Vienna, Austria.

Nelson DM, RP Larson, and WR Penrose. 1987. "Chemical Speciation of Plutonium in Natural Waters." In Environmental Research on Actinide Elements, eds JE Pinder, JJ Alberts, KW McLeod, and RG Schreckhise, pp. 27-48. CONF-841142 (DE86008713), Office of Scientific and Technical Information, U.S. Department of Energy, Washington, D.C.

Nordstrom DK and JL Munoz. 1985. Geochemical Thermodynamics. The Benjamin/Cummings Publishing Co., Inc., Menlo Park, California.

Onishi Y, RJ Serne, EM Arnold, and C E Cowan, and FL Thompson. 1981. Critical Review: Radionuclide Transport, Sediment Transport, and Water Quality Mathematical Modeling; and Radionuclide Adsorption/Desorption Mechanisms. NUREG/CR-1322 (PNL-2901), prepared for the U.S. Nuclear Regulatory Commission, Washington, D.C., by Pacific Northwest Laboratory, Richland, Washington.

Penrose WR, WL Polzer, EH Essington, DM Nelson, and KA Orlandini. 1990. "Mobility of Plutonium and Americium through a Shallow Aquifer in a Semiarid Region." Environmental Science \& Technology 24(2):228-234.

Rai D, RJ Serne, and DA Moore. 1980a. "Solubility of Plutonium Compounds and Their Behavior in Soils.” Soil Science Society of America Journal 44(3):490-495.

Rai D, RJ Serne, and JL Swanson. 1980b. "Solution Species of Plutonium in the Environment." Journal of Environmental Quality 9(3):417-420.

Sanchez AL, JW Murray, and TH Sibley. 1985. "The Adsorption of Pu(IV) and (V) of Goethite." Geochimica et Cosmochimica Acta 49(11):2297-2307. 
Sheppard JC, MJ Campbell, JA Kittrick, and TL Hardt. 1979. "Retention of Neptunium, Americium, and Curium by Diffusible Soil Particles.” Environmental Science \& Technology 13(6):680-684.

Silva RJ. 1984. "The Behavior of Americium in Aqueous Carbonate Systems." In Scientific Basis for Nuclear Waste Management VII, ed GL McVay, vol. 26, pp. 875-881. Materials Research Society Symposium Proceedings, North-Holland, Elsevier Science Publishing Company, Inc., New York.

Silva RJ and H Nitsche. 1995. "Actinide Environmental Chemistry.” Radiochimica Acta 70/71:377-396.

Silva RJ, G Bidoglio, MH Rand, PB Robouch, H Wanner, and I Puigdomenech. 1995. Chemical Thermodynamics Volume 2: Chemical Thermodynamics of Americium. North-Holland, Elsevier Science Publishing Company, Inc., New York.

Silver GL. 1983. "Comment on the Evaluation of the Chemical Forms of Plutonium in Seawater and Other Aqueous Solutions." Marine Chemistry 12(1):91-96.

Sposito G. 1989. The Chemistry of Soils. Oxford University Press, New York.

Sposito G. 1994. Chemical Equilibria and Kinetics in Soils. Oxford University Press, New York.

Stumm W and JJ Morgan. 1981. Aquatic Chemistry. An Introduction Emphasizing Chemical Equilibria in Natural Waters. John Wiley \& Sons, Inc., New York.

Tait CD, SA Ekberg, PD Palmer, and DE Morris. 1995. Plutonium Carbonate Speciation Changes as Measured in Dilute Solutions with Photoacoustic Spectroscopy. LA-12886-MS, Los Alamos National Laboratory, Los Alamos, New Mexico.

Thibault DH, MI Sheppard, and PA Smith. 1990. A Critical Compilation and Review of Default Soil Solid/Liquid Partition Coefficients, $K_{d}$, for Use in Environmental Assessments. AECL-10125, Whiteshell Nuclear Research Establishment, Atomic Energy of Canada Limited (AECL), Pinawa, Manitoba, Canada.

Tuli JK. 2004. Nuclear Wallet Cards for Radioactive Nuclides. National Nuclear Data Center, Brookhaven National Laboratory, Upton, New York. Accessed May 14, 2007 at http://www.nndc.bnl.gov/wallet/wallet4radioactivenuclides.pdf.

Vitorge P. 1992. "Am(OH) $3(\mathrm{~s}), \mathrm{AmOHCO}_{3(\mathrm{~s})}, \mathrm{Am}_{2}\left(\mathrm{CO}_{3}\right)_{3(\mathrm{~s})}$ Stabilities in Environmental Conditions." Radiochimica Acta 58/59(Pt.1):105-107.

Yamaguchi T, Y Sakamoto, and T Ohnuki. 1994. "Effect of the Complexation on Solubility of Pu(IV) in Aqueous Carbonate System.” Radiochimica Acta 66/67:9-14.

Yariv S and H Cross. 1979. Geochemistry of Colloid Systems for Earth Scientists. Springer-Verlag, New York. 